\title{
Executive compensation in Germany
}

\author{
Daniel Beck ${ }^{1} \cdot$ Gunther Friedl $^{1} \cdot$ Peter Schäfer $^{1}$
}

Published online: 31 March 2020

(c) The Author(s) 2020

\begin{abstract}
Understanding executive compensation and its effects helps design better organizations. Research on this area is thus of paramount importance. For large US companies, the ExecuComp database offers access to standardized and comprehensive executive compensation data. Hence, research on executive compensation has strongly focused on US companies. It is not clear that research results based on US data apply to other countries due to differences in corporate governance and culture. We have built up a database that is similar to ExecuComp for Germany, which is by far the largest economy in Europe. This database includes companies from the two largest German stock indices DAX and MDAX. We make these data available for academic research. We describe the data and we provide important results to outline the opportunities that our database offers. We find that only some of the empirical results for US companies such as the association between company size and pay level generalize to German companies while others such as compensation structure and the vertical pay inequality provide opportunities for further investigation.
\end{abstract}

Keywords Executive compensation - Data collection · Corporate governance · Compensation structure

JEL Classification G39 · G34 · J33

\section{Introduction}

How could bank executives walk away with millions after taxpayers bailed out their companies during the financial crisis? Why do executives earn a multiple of the average employee's wage? Are female executives paid less than their male peers? Such questions about the compensation of executives continue to be an issue of academic and public debate. To approach them, we need comprehensive, standardized, and detailed data on executive compensation.

\footnotetext{
$\triangle$ Gunther Friedl

gunther.friedl@tum.de

1 Technical University of Munich, Arcisstraße 21, 80333 Munich, Germany
} 
Executive compensation has been a focal point of corporate governance research. According to Web of Science, about 5000 academic articles have been published in this area over the last three decades. The empirical literature on executive compensation focuses on US companies (Jensen and Murphy 1990; Hall and Liebman 1998) or companies governed by a one-tier board system (Conyon and Murphy 2000; Conyon et al. 2011). Unfortunately, it is not clear that findings based on these data generalize to other countries with different cultural, legal, and institutional conditions. There is a lack of research in this important area on companies outside the US. Research on executive compensation outside the US and on international differences in executive compensation has often been called for (Edmans and Gabaix 2016).

Companies in a governance system characterized by concentrated ownership, shareholders with long-term commitment, and a lack of disciplining mechanisms for management, such as hostile take-overs (Nickell 1995), are an interesting field for empirical research (Conyon and Schwalbach 2000; Fernandes et al. 2013). Germany is the largest economy in Europe and has a system of governance that features many of these characteristics. Unlike US companies, German publicly listed companies are required to have a dual-board structure. The executive board runs the company and is controlled by the supervisory board. Families or endowments are frequently majority shareholders, leading to greater long-term commitment and less opportunity for hostile take-overs. These characteristics render Germany an interesting economy for further research on executive compensation.

A main reason for the focus of empirical studies on the US is that scholars can easily access and collect data on executive compensation of US companies via ExecuComp (Edmans and Gabaix 2016). The database provides standardized data on executive compensation for S\&P 1500 companies from 1992 to the present, and it includes items such as base salary, bonus and stock options, as well as some data on companies' financials. The clear structure of ExecuComp and its easy accessibility have spurred extensive research about the antecedents and consequences of executive compensation in the US. Currently, empirical research on the German compensation system is scarce. ${ }^{1}$ The lack of high-quality, standardized data has been claimed an important reason for few studies with data from outside US (Gabaix and Landier 2008).

The purpose of our work is, first, to provide a database of executive compensation in Germany spanning the time from 2006 until today, second, to exemplify how our database can be used to test state-of-the art theory on executive compensation, and, third, to give insights into the development, determinants, and effects of compensation contracts in Germany. Our database covers large, publicly listed companies in Germany from 2006 to present. The database should enable researchers to compare compensation levels and compensation structures across companies, years, and countries. We have therefore standardized the data as much as possible and adapted it to the structure used by ExecuComp. International studies most frequently rely on the commercial databases S\&P Capital IQ (Correa and Lel 2016), BoardEx (Fernandes et al. 2013), and ISS Incentive Lab (Peng and Yin 2019). S\&P Capital IQ provides

\footnotetext{
${ }^{1}$ Exceptions include Rapp and Wolff (2010), Rapp et al. (2011), Sommer et al. (2013) and Hitz and Müller-Bloch (2015).
} 
information on salary, bonus, total cash, and equity compensation. BoardEx splits total compensation into salary, bonus, other pay, and pension and equity compensation. Studies focusing on German companies often rely on hand-collected data sets (Rapp and Wolff 2010; Rapp et al. 2011; Sommer et al. 2013; Hitz and Müller-Bloch 2015).

Our database provides individual compensation information on all executives of the 80 largest companies listed in Germany. The database is structured like ExecuComp, tailored to the needs of researchers, and in a ready-to-use format. Distinct data tables allow for the most common analyses in this field, including research on individual executives and the entire top management team. Our data spans the years 2006 to present and is going to be updated annually. We aim at facilitating future empirical research on the topic and at encouraging replication studies of previous findings on executive compensation in the US. In general, we follow the structure of ExecuComp if possible. We provide total compensation for all executives employed in companies of our database. In addition, researchers analyze the use and behavioral effects of particular components such as stock options or accounting bonuses (Edmans et al. 2017; Shue and Townsend 2017; De Angelis and Grinstein 2014; Wiseman and Gomez-Mejia 1998; Sanders 2001; Bolton et al. 2015; Guay 1999; Lewellen 2006; Armstrong and Vashishtha 2012). In particular, the literature has increasingly focused on the duration of compensation (Gopalan et al. 2014, 2016; Flammer and Bansal 2017; Ladika and Sautner 2018). Accordingly, we disaggregate total compensation into fixed salary, one-year bonuses, multi-year bonuses, stock-based compensation, pensions and one-time payments. ${ }^{2}$ Additionally, we provide qualitative data on the compensation components, performance measures, and performance duration used.

Because compensation data disclosed by companies are not easily comparable across companies and over time, we need to deal with some classification issues. To comply with legal requirements, companies need to fit their specific compensation system into a single reporting framework. This works well for many compensation components but becomes challenging for some incentive structures. For instance, a cash bonus depending on total shareholder return may create similar incentives as a share grant but is subject to different disclosure requirements. ${ }^{3}$ Moreover, the disclosure regulation evolves over time. This leads to a discontinuity in the compensation information disclosed by companies. Collecting compensation data that allows for comparisons across countries, companies, and over time requires therefore a solid understanding of the mechanisms behind the compensation systems that generate such data. Thus, we elaborate on some important design choices in Sect. 3.

\footnotetext{
2 Pension provisions for executives and one-time payments have recently received more attention. Some argue that pension promises mean executives participate in the company's debt and therefore analyze incentives provided by debt-like compensation components (Sundaram and Yermack 2007; Wei and Yermac, 2011; Cassell et al. 2012). Finally, some authors focus on one-time payments such as "golden hellos" (Xu and Yang 2016). We therefore collect costs for executives' pension promises and one-time payments to executives separately.

3 The German Commercial Code together with the German Accounting Standard No. 17 requires a cash bonus to be reported once all requirements for the bonus have been fulfilled and requires stock grants to be reported at their granting date. A cash bonus depending on the total shareholder return over two years and a stock grant with a vesting period of two years would create an identical payout scheme and thus identical incentives but would be reported at different points in time. See Sect. 3.2 for details.
} 
We use our database to examine the development, determinants and effects of executive compensation in Germany. First, we find that the growth in executive compensation has slowed down between 2006 and 2018 compared with the previous decades, and that the growth has further slowed down in the later years of our database. In line with most international empirical findings, we find that executive compensation levels are associated with a company's size, risk, and success. The growth of executive compensation levels in the years of our analysis can be fully explained by the growth of companies' sizes. We find evidence that compensation levels are positively correlated with both individual company sizes and aggregated company sizes. However, the correlation with aggregated company sizes is less time-consistent than the correlation with individual company sizes. Different from prior results (Edmans et al. 2017), we find that older and longer-tenured executives earn on average more than their younger colleagues. With respect to the structure of compensation, we find a significant shift from short-term bonuses to long-term equity compensation. Finally, we analyze vertical pay inequality, the ratio of a CEO's compensation and the mean employee compensation. The literature refers to this as the CEO pay ratio. The median pay ratio in our sample increases from 43 in 2006 to 53 in 2018. Similarly to Rouen (2020), we find some evidence that vertical pay inequality that can be explained by economic factors is positively associated with future firm performance. Moreover, vertical pay inequality that cannot be explained by the respective economic factors is negatively associated with future firm performance.

Overall, our findings suggest that some determinants and developments of executive compensation generalize to other countries and periods while others do not. For example, the size of a company seems to be a time-consistent determinant of executive compensation in Germany as well. On the contrary, the compensation growth rates change significantly between decades. The association between the aggregated company size and the compensation levels also changes over time. Additionally, we observe strong differences between Germany and the US with respect to the compensation structure and the vertical pay inequality. It is reasonable that, for instance, different disclosure requirements, tax policies, or labor market parameters can cause differences in executive compensation levels and structures (Murphy 2013). Crosscountry studies provide a promising opportunity for future research if we want to better understand the role of such factors and the driving forces behind compensation contracts in general. With our database, which we make accessible to interested scholars, we are taking a step forward to facilitate such studies.

The remainder of this article is structured as follows: In Sect. 2, we illustrate examples of compensation systems of German companies and elaborate on the regulatory environment for the disclosure of executive compensation in Germany. In Sect. 3, we describe our database. We propose and discuss a classification scheme for German data on executive compensation. Subsequently, we describe the coverage of our data and the variables used in our database in detail. We provide analyses of determinants and the development of executive compensation in Germany in Sect. 4 and conclude in Sect. 5. 


\section{Background: executive compensation and its regulatory environment in German}

\subsection{Determination and an example of executive compensation in Germany}

How to compensate executives is a much discussed and critical issue for companies. Several parties are involved in the process of setting compensation plans. In Germany, the main responsibility lies with the supervisory board. Its members steer the design of compensation contracts, frequently with support of compensation consultants. They also evaluate the individual performance of executives to determine bonus payments. On the annual general meeting, shareholders may issue non-binding say-on-pay votes to show whether they agree with the remuneration of their executive board members. Companies tailor executive compensation contracts to their specific needs and presumably to the characteristics of the executive. To illustrate the variety of parameters that determine a compensation system such as performance measures, performance targets, and performance periods, we shortly summarize the compensation of Martin Brudermüller, the CEO of the chemical company BASF SE. ${ }^{4}$

In 2018, Brudermüller earned a fixed salary of EUR $1.4 \mathrm{~m}$ and additional fringe benefits of EUR $0.1 \mathrm{~m}$. His compensation package included a bonus that depended on operational targets, strategic mid-term objectives, and the return on capital employed. BASF reports a target bonus of EUR $1.6 \mathrm{~m}$ that Brudermüller missed in 2018, earning only EUR $1.4 \mathrm{~m}$. The same amount was granted as a forward bonus. It can lead to an even larger payment if Brudermüller achieves certain strategic targets by 2021 . Additionally, Brudermüller was entitled to an option program worth EUR $0.9 \mathrm{~m}$ in 2018. The options have a vesting period of four years and can then be exercised for four years - conditional on whether Brudermüller meets the absolute performance threshold of increasing the BASF share price by at least 30 percent and whether the company's shares outperform the MSCI World Chemicals Index. Finally, BASF contributed EUR $1.1 \mathrm{~m}$ to the pension plan of its CEO in 2018. Overall, this example illustrates the highly complex structure of a German managing board level compensation contract.

All companies listed on the DAX or MDAX in 2018 used a base salary to pay their executives. Over 90 percent of these companies use a variable short-term component in their compensation system and more than 50 percent rely on non-equity based multi-year bonuses. Additionally, around 70 percent use stocks or stock options in their compensation plans and more than 80 percent use pensions.

\subsection{Regulatory environment of executive compensation in Germany}

Various regulations oblige German companies to disclose information on executive compensation. The German Commercial Code (Handelsgesetzbuch, GCC) serves as general basis for the disclosure requirements of German companies and regulates the disclosure of executive compensation. The Executive Compensation Disclosure Act (Vorstandsvergütungs-Offenlegungsgesetz, CDA) has extended these requirements for

\footnotetext{
4 See BASF's annual report for 2018.
} 
compensation disclosure since 2005. Besides these mandatory provisions, the German Corporate Governance Code (Deutscher Corporate Governance Kodex, the Code) governs the reporting requirements of executive compensation in Germany. Additionally, the provisions of IFRS 2 and IAS 24 apply to German capital market-oriented companies.

The CDA became effective in August 2005 and requires publicly listed companies to disclose the compensation of executives at the individual level. It imposes the separate disclosure of performance independent compensation, performance dependent compensation, compensation with long-term incentives, and deferred compensation. The CDA allows companies to opt out from these disclosure requirements following a confirmatory decision by the general annual meeting.

The Act on Appropriateness of Management Board Remuneration (Gesetz zur Angemessenheit der Vorstandsvergütung, AMBR) became effective in 2009. It influences both the level and the structure of executive compensation. Specifically, the compensation level should be comparable to other companies of similar size within the same industry and it should be proportionate to employees' salaries within the company. The compensation should also reflect the economic situation of a company and should be aligned with its sustainable, long-term development. The AMBR assigns the responsibility to comply with these regulations to the supervisory board.

The Code is a set of guidelines for good corporate leadership of publicly listed companies. Though it is not legally binding, the Code strongly affects the transition of existing regulations into practice and, thus, the landscape of executive compensation and its disclosure in Germany. For instance, it recommends the use of fixed and variable pay, where the latter should be based on a multi-year base of assessment and it should be capped. The Code does not only provide recommendations for compensation practices, but it also guides companies on how to disclose executive compensation. For example, in its version of 2014 to 2019 , the Code recommended disclosing amounts paid to executives, but also newly granted bonuses or equity that will not lead to payouts to the executive until subsequent years. Companies should separately report base salary, short-term variable pay, and long-term variable pay. The Code provided standardized templates as shown in Appendices Tables 6, 7 for this purpose, but it dismissed these standardized templates in its latest version. Moreover, there will be new guidelines for the structure and disclosure of executive compensation. The latest version will be formally published only after the implementation of the new shareholders' rights guideline (ARUG II) that was approved in November 2019. Therefore, disclosure of executive compensation in Germany will change again.

\section{Database: systematic collection of executive compensation in Germany}

\subsection{Data structure and obstacles}

Since 2006, it is mandatory for German publicly listed companies to disclose the compensation of each executive and to distinguish several compensation components. This enables empiricists to test theories on executive compensation with German data. 
We want to facilitate research on German companies and, to this end, provide a database that enables comparisons between companies, countries, and across years. To allow for comparisons with US companies and for the replication of studies performed using US data, we provide a classification that is as similar as possible to ExecuComp. We outline the data structure, major classification obstacles, and our solution approaches in this and the subsequent section. We compare our database to ExecuComp in Sect. 3.3.2 and name corresponding variables of both databases in Panel 2 in Appendix Table 8.

We categorize compensation into the following components: (1) performance independent compensation, (2) one-year bonuses, (3) multi-year bonuses, (4) stock-based compensation, (5) pensions, and (6) one-time payments. Performance independent compensation comprises fixed salary and other compensation, such as fringe benefits. A one-year bonus is a performance-dependent compensation element that depends on the assessment of one or multiple performance measures for one year only and that is paid out in cash. A multi-year bonus depends on the assessment of one or multiple performance measures other than the stock price development for more than one year and is typically settled in cash. We define a compensation element as stock-based compensation if its performance measures are solely based on the company's stock price development or if the compensation element is paid out in stock. Stock-based compensation comprises stock and stock options. Pensions comprise additions to pension accruals. One-time payments are non-recurring payments, such as a signing bonus or severance pay.

Our categorization allows the intended comparison with US companies. However, the structure required by GCC and suggested by the Code does not match our categorization which leaves us with some required judgements of how to account for certain compensation components. For instance, the CEO of Wirecard AG Markus Braun received a multi-year bonus in 2018 that depends on the average EBITDA growth and the total shareholder return relative to the TecDAX. Arguably, one could classify this bonus as a multi-year bonus or as stock-based compensation. One could instead also split up the bonus and assign only parts as the respective compensation elements.

Moreover, German lawmakers and policymakers have changed the requirements for reporting compensation data over time. Especially the provision of standardized templates and the suggestion to distinguish between paid and granted compensation by the Code changed the reporting landscape starting 2014. This raises questions about how to deal with this new information. For example, the CEO of Allianz SE Oliver Bäte received a mid-term bonus in 2018 that depended on several performance measures over the period from 2016 to 2018. One could consider the value paid in 2018 as compensation in 2018 or one could consider the value granted in 2016 as compensation in 2016.

Finally, in some cases not only the classification but also the level of compensation leaves us with some leeway. In 2018, Bäte received restricted stock units that have a vesting-period of four years and for which the granted value depends on the annual bonus of the prior year. It is not entirely clear how one should value these stock grants. Bäte also acquired pension entitlements for the period after his retirement. Because pension system are highly specific to a country and because Germany companies use different pension system, it is unclear whether and with what value these pension claims should be accounted for. Thus, we discuss these categorization and valuation 
difficulties in the next section. We outline what information companies need to disclose and how we use them in order to provide a consistent database.

\subsection{Classification and valuation difficulties}

\subsubsection{Accounting for multi-year bonuses}

The payout of a multi-year bonus depends on performance over a period of two or more years. Thus, incentive plans granted in a particular year generate payouts in later years. For example, Adidas AG agreed in 2006 to pay a bonus in 2008 depending on the accumulated earnings before taxes between 2006 and 2008. With this agreement, Adidas promised a payment for the executives' performance in the years between 2006 and 2008. However, the payment was only made in 2008 and the payment is uncertain in amount as of 2006. There are several possibilities as to how to disclose and how to collect the amount earned from this multi-year incentive plan. Do the executives earn the bonus in 2006, spread over the years 2006 to 2008, or in 2008, when they receive the cash?

First, a company may disclose the payments from a multi-year bonus. Adidas would report a zero multi-year bonus for 2006 and 2007 and the full amount paid in 2008. Second, the company may disclose the granted amount. In this case, Adidas would report the full amount of the multi-year bonus in 2006. If a company reports the granted amount, it needs to make an assumption about the future development of the applied performance measure. For example, a company may report the level of compensation under a pre-defined target performance or the level of compensation it deems most likely. Third, a company may report future payments that are actually realized and to which the manager is legally entitled, thereby following a realization principle from the executives' perspective. In the Adidas example, the reported compensation would depend on the exact design of the bonus agreement and the achieved performance. If the bonus paid in 2008 is the sum of bonuses earned in the years 2006, 2007, and 2008, Adidas would report the amount that the executive received for the performance in 2006, 2007, and 2008 in the respective year. If the whole bonus paid in 2008 depends on the criterion that a certain threshold performance is achieved in each year of the performance period, Adidas would report realized compensation from the bonus agreement only for 2008. Finally, a company may report its expenses in the respective year. This would mean to calculate the expected payout in 2008 - given the performance up to the current point of time-and to calculate the prorated value for the respective year.

The several disclosure standards that apply to German companies suggest different ways of accounting for multi-year bonus agreements. The GCC together with the German Accounting Standard No. 17 follows the realized compensation principle. When a company has made a legally binding commitment to a particular payment and all conditions have been fulfilled, the company needs to report the respective value. In contrast, the Code has required companies since 2014 to report paid and granted values separately. For the granted value, the Code requires disclosure of the future compensation that an executive receives based on a performance target or the 
performance in an average probability scenario. However, the Code distinguishes bonus plans that are granted annually and bonus plans that are regularly granted in a sequential manner. In the latter case, the company reports a ratable value on an annual basis. Finally, the IFRS require the company to report the expenses of a respective year. However, they do not require a company to report the remuneration of each executive separately.

Prior to 2014, the Code did not demand that paid and granted values are disclosed separately. Hence, companies only had to follow the GCC regulation and to report the realized compensation. For these years, we collect the realized compensation that companies had to report according to the GCC regulation. From 2014 onwards, we report both the granted and paid compensation as companies that comply with the Code report both numbers separately. We carefully checked our database for deviations between realized compensation and paid compensation. Since we do not find any deviation, we suggest using realized compensation until 2014 and using paid compensation afterwards as a measure of executives' multi-year bonus.

\subsubsection{Distinguishing multi-year bonuses and stock-based compensation}

Many companies_-including our example Wirecard—use both stock-based and nonstock-based performance measures in their multi-year compensation plans. We seek to distinguish incentives based on stock-based measures and incentives based on nonstock-based measures. Sometimes, it is difficult to classify compensation elements as either a multi-year bonus or stock-based compensation. The classification might depend on the level of detail of the underlying compensation report.

We unambiguously classify stock or stock options as stock-based compensation. However, many companies use compensation elements involving the stock price as well as other performance measures. In the simplest case, the vesting of an option or virtual stock depends on performance criteria involving non-stock-based performance measures. Moreover, some companies make the number of granted stocks dependent on the target achievement of non-stock-based performance measures. The remuneration system of SAP in 2018 illustrates such an arrangement, where the target value of granted stocks depended on the operating profit for the previous year. Finally, some companies report long-term incentive programs involving the stock-price and other performance measurements - with or without disclosing the compensation formula or the weights of the different performance measures. For instance, Wirecard weights each of the three performance measures EBITDA growth, share price performance, and relative total shareholder return equally when determining the granted amount of its multi-year bonus.

We define a compensation element as stock-based compensation if its performance measures are solely based on the company's stock price development or if the compensation element is paid out in stock. The latter includes stocks with performance criteria and stock programs with the amount of granted stock depending on accounting-based performance criteria. If a company uses a long-term incentive program with stockbased and non-stock-based performance criteria without separating the compensation accordingly, we classify the respective compensation component as multi-year bonus because we cannot reliably distinguish the extent to which the component depends 
on stock- and non-stock-based performance criteria. Even when a company provides weights of the different performance measures, we cannot properly split the amounts accordingly because these weights usually refer to the target compensation structure.

Our database does not distinguish phantom stock or virtual stock options from actual stock or stock options. This is justified by the fact that both exhibit very similar costs to shareholders and very similar incentive effects. However, potential dilution of shareholder's equity thus cannot be analyzed.

\subsubsection{Accounting for stock-based compensation}

Stock-based components have become part of most compensation systems in Germany over the last few years. In 2018, around $70 \%$ of companies listed on the DAX or MDAX used stock or stock options in their executive incentive schemes. In most cases, companies grant their executives stock in a given year. The amount or value of granted stock sometimes depends on one or multiple performance criteria. Stockbased programs usually have a vesting period of several years and the executive can only sell the stock if he or she meets certain performance criteria.

Even though stock-based incentives are a specific multi-year bonus, the disclosure requirements for stock-based compensation differ from disclosure requirements for other multi-year bonuses. National accounting standards, such as US-GAAP, and the IFRS require companies to report stock-based compensation at its fair value in the year of the granting date. The Code and GCC follow this provision as well. Hence, we use the fair value of granted stock-based compensation in our data definition. ${ }^{5}$

\subsubsection{Accounting for pensions}

To provide executives with post-employment benefits, companies either use defined contribution plans or defined benefit plans. In a defined contribution plan, a company makes a regular contribution to an executive account. The company has no obligations toward the executive beyond this contribution. Post-employment benefits for the executive therefore depend on the investment earnings of his or her account. In a defined benefit plan, a company agrees to pay its executive a pre-determined amount after his or her retirement, either as regular pension payments or as a lump sum. The payment amount usually depends on criteria such as the tenure and salary of the executive.

Companies using a defined contribution plan typically report the yearly contributions to the pension accounts of their executives. Companies using a defined benefit plan usually report the increase in the present value of pension provisions that depends on the performance of their executives in the current period. Yet, some companies only disclose one figure that includes, in addition, the net interest on and changes in the

\footnotetext{
5 The standard setter does not intend fair value accounting for other multi-year bonuses, presumably because it is difficult to define a fair value for most non-equity based multi-year bonuses. If it were at all possible to derive a fair value for a multi-year bonus that is based on a number of accounting performance measures, many assumptions would be necessary. The standard setter could hardly standardize such assumptions with sufficient precision for an accounting standard. On the contrary, stock is reported at its fair value and there exist established models to value stock options such as the Black-Scholes model.
} 
present value of provisions that exist from prior periods. As these components can be negative, pensions reported by a company can be negative as well.

We report the yearly contributions (changes in the present value attributable to the current period) whenever possible. We note that some companies only disclose pensions attributable to the entire board before 2014, despite disclosing other compensation components at the individual level. Moreover, companies regularly report pension values of zero, which can have three reasons: First, a company does not grant its executive pensions as part of his or her compensation. Second, a company agrees to pay its executive a higher salary and the executive is responsible for making pension arrangements him- or herself. Third, a company uses a defined benefit plan and the executive has already earned the maximum amount of his or her pension in previous years. Comparing pensions across companies can therefore be challenging. Consequently, we report two values of total compensation for each executive-one excluding and one including pensions.

\subsection{Description of database}

\subsubsection{Data coverage and collection}

Our database covers the executive compensation of companies listed on the DAX or MDAX from 2006 until 2018 at the individual level. ${ }^{6}$ Specifically, we provide three distinct data tables. The first table contains compensation data on a person-year level. For each executive, we collect and provide information on his or her (1) salary and other annual compensation, (2) one-year bonus, (3) multi-year bonuses, (4) stock-based compensation, (5) pensions, and (6) one-time payments. We also include information on whether an executive held the position as CEO or CFO and how many days he or she spent on the board. This table excludes executives working for companies that opted out from disclosing compensation for each executive individually. ${ }^{7}$ This is possible following a decision at the shareholders' meeting of a company. However, our second data table, containing compensation data on a company-year level, includes all companies. We provide the same compensation variables as in the first table at the company level. In addition, we include variables aggregated at the board level, such as the number of active executives and the total number of days served by all executives during the year. Further variables specify fiscal year information and listing on the DAX or MDAX.

The third data table enriches the compensation data with personal information on the executive at the company-person level. Most executives appear once in the data table. However, some executives in our database move from one company to another

\footnotetext{
6 The latest version of the database can be retrieved for academic purposes from the authors' website.

7 Companies in our database opted out in 189 out of 1,200 company-year observations. Hence, analyses at the person-year level are possible for the major part of our database. We also tested whether analyses with the companies that did not opt out from the person-specific disclosure may suffer from a selection bias. There is no significant difference in the average total compensation between company-years in which companies opted out and in which they did not. While there is a significant difference in the size of companies, there is no significant difference in its effect on the average total compensation. This observation mitigates concerns about a potential selection bias.
} 
and thus appear more often. We include a unique executive identifier in this table to facilitate tracking such cases. For each executive, we collect his or her date of birth, gender, nationality, company entry date, board entry date, and board exit date (if applicable).

We also publish a fourth data table, including qualitative information to allow future research on more detailed aspects of compensation. This table provides data on the person-year level. We include information about how many performance measures are used, which performance measures are used, the length of performance periods, and the like. The international securities identification number (ISIN) serves as unique company identifier throughout all tables. Appendices Tables 8, 9, 10 list and define all variable of our database.

We collected our data in a multi-step process over many years. The process is as follows: First, we gather information at the company level. Relevant company information includes its legal form, its fiscal year end and beginning, as well as the dates when the company was first listed on or unlisted from the DAX or MDAX. We collect this information from annual reports and constituents lists from Deutsche Börse. Second, we gather general information at the person level, such as company entry or exit dates or dates an executive became CEO or CFO. Third, we collect information on the annual compensation of executives at the individual level. We repeated this process on a yearly basis for all years from 2006 to 2018. We had the compensation data double-checked by people not involved in the original collection. ${ }^{8}$ Finally, to ensure data quality, the authors identified and reviewed cases that were difficult to classify as well as a set of randomly drawn cases.

\subsubsection{Data definition}

Variables at the person-year level are listed and defined in detail in Appendix Table 8. The compensation components salary, other annual compensation, and one-year bonus follow the realization principle for the years 2006 to 2013 and are based on the compensation paid to the executives for the years 2014 to 2018 . We report one figure for multi-year bonuses that is based on the realization principle for the years 2006 to 2013. We provide two figures for the years 2014 to 2018: multi-year bonus grants and multi-year bonus payout. These are based on the amounts granted and the amounts paid in each year. Stock grants and stock option grants are listed at their fair value at the granting date, as reported by the company. Following the discussion in Sect. 3.2, we define a multi-year bonus as a non-equity compensation item that uses more than one year as period of assessment. When a multi-year bonus is either paid in stock (or stock options) or uses only stock-based performance measures, we classify it as a stock (or option) grant instead.

\footnotetext{
8 We acknowledge the most valuable help of all people involved in this process. In particularly, we want to thank Thorsten Döscher, Andrea Dötsch, Christoph Heilmann, Cornelia Hojer, Julia Holzmann, Tim Kettenring, Christoph Klink, Verena Limbrunner, Julian Ludat, Lambert Neumayr, Iris Pfeiffer, Fridolin Pflugmann, Christopher Scheubel, Verena Springer, Christian Stoll, and all the students involved in the data collection. Additionally, we thank Christiane Hölz, Marc Tüngler and Ulrich Hocker from the Deutsche Schutzvereinigung für Wertpapierbesitz e.V. (DSW) for many helpful discussions on the classification of compensation systems. Our database also serves as basis for annual studies on executive compensation in German companies in collaboration with the DSW. The latest study is Friedl et al. (2019).
} 
There are also two figures for total compensation. The first figure is based on the GCC together with the German Accounting Standard No. 17 and defines total compensation as the sum total of salary, other annual compensation, one-year bonus, multi-year bonus, and stock-based grants. For the years 2014 to 2018, we use the amounts paid for all non-equity compensation components and the granted amounts for stock-based compensation. The second figure includes, in addition, pensions and one-time payments.

Appendix Table 9 gives the definitions of the company-year variables. Compensation related variables at the company level are defined similarly to the respective variables at the individual level. For companies disclosing compensation at the individual level, we calculate total board compensation as the sum of the variable at the individual level. For companies that chose to opt out, we report the total amounts disclosed by the company.

Appendix Table 10 defines the company-person variables. Each executive is uniquely identifiable by his or her executive ID to allow tracking him or her between different employments. Company-related variables, such as company entry dates or board entry dates, are taken from annual reports as the primary source. We enrich this data with personal information, such as nationality and gender, collected from annual reports and through additional online research.

Our data tables are structured similarly to ExecuComp (see Panel 2 in Appendix Table 8). We define total compensation as the sum of salary and other annual compensation, one-year bonuses, multi-year bonuses, and stock-based compensation. We provide one data item where we additionally include pensions and one-time payments. Since 2006, ExecuComp defines total compensation as the sum of salary, other compensation, bonuses, non-equity incentive plan compensation, option grants, stock grants, and deferred compensation. Salary, other compensation, and one-year bonuses are based on the amounts awarded and paid in the same year in both databases. In our database, multi-year bonuses exclude compensation that is solely based on the development of a company's stock price. The amounts that we show are based on the amounts realized up until 2013 and on the amounts paid after 2014. ExecuComp uses the payout of non-equity incentive plan in its definition. Given that the Code suggests reporting the amounts paid and granted individually since 2014, we deem our definition as comparable as possible. However, we also provide the amounts granted since 2014.

Stock-based compensation components are provided at their granting-date fair value as reported by the company according to its national regulation in both databases. We provide two variables for the total compensation. One of them includes and the other excludes pensions. ExecuComp includes pensions in its definition of total compensation. Because the pension system in Germany is very different from the pension system in the US, we suggest being careful when comparing these items. Drawing inferences on executives' inside debt in Germany can be especially difficult because defined benefit plans do not expose executives to debt-like risk. Besides the items in our database, ExecuComp provides more additional information on companies such as their dividend yield, their numbers of employees, and several numbers related to the development of earnings per share. Using our compensation database, one needs 
to collect this information from other financial databases such as Worldscope and Datastream.

\section{The development of executive compensation in Germany between 2006 and 2018}

\subsection{Theories and current questions on executive compensation}

Executive compensation has been increasing in many countries over the last decades (Gabaix and Landier 2008; Murphy 2013). This has not only fueled public outrage but also intensified the academic debate about the drivers of executive compensation and reasons for its increase (Edmans et al. 2017; Göx 2016). In Germany, the board of directors is responsible for choosing the level and structure of executive compensation. Academics and practitioners debate heavily whether directors set compensation contracts fully acting in the interest of shareholders (the literature refers to respective theories as the "shareholder value view" or as the "optimal contracting view") or whether powerful executives can affect the process of setting compensation contracts to their own advantage ("managerial power approach" or "rent extraction view"). ${ }^{9}$ If directors act in the interest of shareholders, they hire executives and choose compensation structures to maximize shareholder value. ${ }^{10}$ Executive compensation contracts should then be an outcome of the labor market and contract negotiations between directors and executives. The analysis of properties of the labor market and the relationship between shareholders and executives that is governed by the compensation contract would allow the prediction of certain characteristics of compensation contracts.

Companies compete for talented executives. If large companies benefit more from talented executives and if the labor market for executives is efficient, the largest companies hire the most talented executives but need to attract them with high compensation. Hence, the optimal level of executive compensation should increase in company size but also increase in the aggregated size of all companies in the market (the literature refers to the respective models as "assignment models"; e.g., Gabaix and Landier 2008; Tervio 2008). The competition for executive talent may have intensified over time because today's companies need general managerial skills more than company-specific knowledge (Murphy and Zabojnik 2004, 2007; Frydman 2019). Hence, assignment models predict that, first, executive compensation increases over time and, second, the compensation inequality among executives increases over time.

Directors need not only to find talented executives but must also ensure that hired executives behave in the shareholders' interest. Executives may have different interests than maximizing shareholder value. They may, for example, be averse to exerting effort or bearing risk. Because directors and shareholders cannot directly observe whether executives spend their best effort to manage the company, an agency problem arises (Jensen and Meckling 1976; Jensen and Murphy 1990; Murphy 1999). The most

\footnotetext{
9 For overviews of this debate, see for instance Friedl (2012), Murphy (2013) or Edmans et al. (2017).

10 Supervisory board members in Germany are partly determined by employees rather than shareholders. This might have an effect on executive compensation (e.g., Döscher and Friedl 2011).
} 
prominent solution to mitigate this agency problem and to incentivize executives to act in the interest of shareholders is to compensate them depending on the company's performance. However, while shareholders typically hold well-diversified portfolios, executives have high personal stakes in their company's success (e.g., Nam et al. 2003). Hence, shareholders and executives share the risk of the company's performance suboptimally. Models predict that compensation increases in companies' performance and risk. Over the last decades, researchers have extended the agency models from the 1970s and $80 \mathrm{~s}$ (Holmström and Milgrom 1987), they have integrated more executive decisions in the models (e.g., Aggarwal and Samwick 1999; Gopalan et al. 2010), they have focused on additional information that may be used in contracts (e.g., Holmström 1979, 1982), and they have considered different contractual constraints and frequently observed pay elements such as stocks and options (e.g., Guay 1999; Lewellen 2006; Armstrong and Vashishtha 2012; Bolton et al. 2015; Shue and Townsend 2017). ${ }^{11}$

Compensation contracts will only efficiently mitigate agency conflicts if directors set the contracts in the shareholders' best interest. However, executives may exploit weak governance mechanisms to earn higher compensation or to decrease payfor-performance sensitivity (Bertrand and Mullainathan 2001; Bebchuk et al. 2002; Bebchuk and Fried 2003, 2004). Then, executive compensation is not only a means to mitigate agency problems between owners and executives but it would be a part of the agency problem (Bebchuk and Fried 2003, 2004). For example, directors who set executive compensation systems may have social connection to the executives and feel loyal to them. Additionally, executives may affect the compensation contracts via the choice of directors. These arguments are particularly interesting to test in Germany because directors and executives are strictly separated organizationally under the German two-tier system. This raises the question of whether influencing boards and compensation contracts is more difficult for executives in Germany than in other countries (Göx 2016).

Empirical analyses of executive compensation can help us understand the factors that influence executive compensation contracts and, ultimately, whether they efficiently govern agency conflicts between executives and shareholders. A great deal of effort has been put into testing theory with executive compensation data, but the large majority of empiricists use data from the US (Gabaix and Landier 2008; Edmans et al. 2017). In this section, we provide some insights about the development, determinants, and effects of compensation contracts in Germany using our database. Thereby, we highlight how empiricists can use our database to improve our understanding of executive compensation outside the US. First, in Sect. 4.2, we analyze the development of executive pay levels between 2006 and 2018 in Germany and test whether well-known determinants for executive pay levels explain growth in compensation levels. Second, in Sect. 4.3, we analyze the development of executive compensation structures. Third, in Sect. 4.4, we re-examine findings on one of the most important determinants for executive pay: the size of the company. Fifth, in Sect. 4.5, we analyze the development of vertical pay inequality by comparing CEO and mean employee compensation. In this respect, we replicate a recent study by Rouen (2020) who finds that pay inequality that can be explained by economic factors is positively correlated

11 Murphy (2013) and Edmans et al. (2017) provide comprehensive surveys on the topic. 


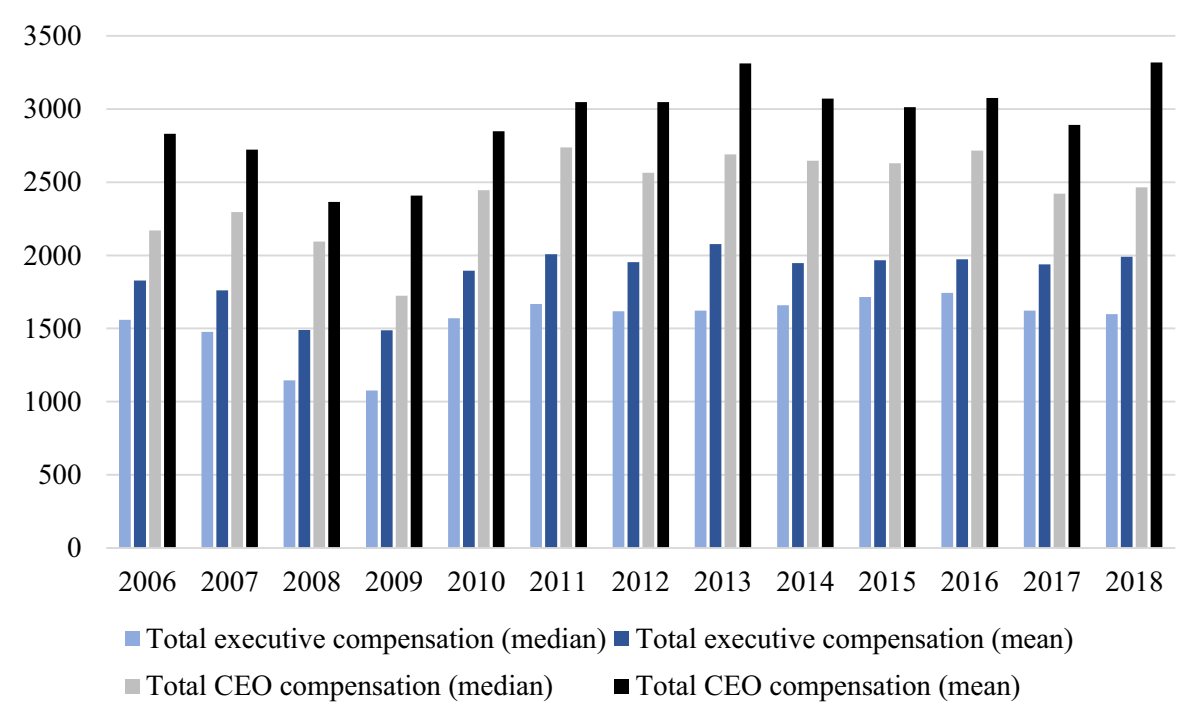

Fig. 1 Total compensation of executives of German companies from 2006 to 2018

with future company performance while pay inequality that cannot be explained is negatively correlated with future company performance.

\subsection{Development and determinants of total compensation}

In the US, executive compensation levels rose sharply between the early 1990s and the middle of the last decade (Bebchuk and Grinstein 2005; Murphy 2013; Edmans et al. 2017). While executives of US companies still earn more than their colleagues in other countries (Fernandes et al. 2013; Edmans et al. 2017), German executives significantly increased their compensation between 1990 and 2010 as well (Göx 2016). Figure 1 illustrates the development of compensation in recent years. The total compensation of an executive of a DAX or MDAX listed company increased on average by 9 percent from EUR $1.83 \mathrm{~m}$ in 2006 to EUR $1.99 \mathrm{~m}$ in 2018 . $^{12}$ This corresponds to a compound annual growth rate of 0.7 percent. The median compensation increased by only 3 percent from EUR $1.56 \mathrm{~m}$ to EUR $1.60 \mathrm{~m}$ in the same period, or a compound annual growth rate of 0.2 percent. Relative to the increase in the decades before, executive compensation almost stalled in recent years. For comparison, the median executive compensation at DAX companies septupled during the three decades from 1985 to 2014 (Göx 2016).

The compensation of CEOs increased at a slightly higher rate than the compensation of other executives. The mean total compensation increased by 17 percent from EUR $2.83 \mathrm{~m}$ in 2006 to EUR $3.32 \mathrm{~m}$ in 2018; the median total CEO compensation, by 13 percent from EUR 2.17 to EUR $2.46 \mathrm{~m}$. We compare these numbers with compensation growth rates in the US using data from the ExecuComp database. Between 2006

\footnotetext{
12 Throughout this Section, we use real measures of compensation based on the year 2006. Yearly inflation rates are taken from the World Economic Outlook Database of the International Monetary Fund.
} 
and 2018, the average CEO compensation in all companies increased from USD 5.81 to USD $6.53 \mathrm{~m}$; the median CEO compensation, from USD 3.29 to USD $4.72 \mathrm{~m}$. This constitutes an increase of 12 percent in the mean and an increase of 43 percent in the median of CEO compensation. Hence, the reduced growth rates in executive compensation after 2006 compared to the preceding time period are not specific to German companies.

Many researchers focus on determinants of executive compensation levels. A recent example are Edmans et al. (2017) who examine how CEO compensation levels correlate with company and CEO characteristics in the US. We perform a similar analysis for all executives in our German database. We include a continuous time trend to test whether the observed differences in the development of executive compensation in Germany are statistically significant. Specifically, we regress the natural logarithm of total executive compensation on a continuous time variable and a vector of company and person-level variables, the company risk and performance, as well as the executive's age, tenure, position (CEO, CFO) and gender. Additionally, we split our data into the periods 2006 to 2012 and 2013 to 2018 to test whether the development of compensation levels systematically changed over time. We present results from this analysis in Table 1.

We find a significantly positive but economically small time trend when we include time as only regressor (column 1). Once we control for company size, we find no significant time trend (column 2). Column 3 of Table 1 provides some indication that growth rates between 2006 and 2012 were higher than growth rates between 2013 and 2018. Overall, these results are in line with the notion that the growth in executive compensation flattened after 2006. Further, we find that company size and risk as well as an executive age and tenure are positively associated with compensation levels (columns 4-6). CEOs earn higher compensation levels than other executives and there is some indication that so do CFOs. We find some evidence that, on average, female executives earn less than their male colleagues. Finally, total compensation is positively associated with prior year's shareholder return but not with current year's shareholder return (column 6). ${ }^{13}$

Much research has documented a rapid increase in executive pay since the 1980s (Frydman and Jenter 2010; Frydman and Saks 2010; Murphy 2013). However, if we zoom out of the relatively short-term view and look at a longer period, we see that growth in executive compensation levels strongly differs at different times. Frydman and Saks (2010) find a J-shaped relationship and strongly differing growth rates between 1935 and 2005 in the US. We find that the increase in executive compensation in Germany has slowed down in recent years compared to the last decade of the twentieth century and the first years of the twenty-first century. Our findings underline that growth rates can vary greatly at different times and in different countries. While much

\footnotetext{
13 The question of whether and how strongly executive compensation is related to company performance is heavily debated in the literature (e.g., Hall and Liebman 1998; Hall and Murphy 2002). Some studies find a positive relation between company performance and executive compensation (e.g., Conyon and Murphy 2000; Hartzell and Starks 2003), which is, however, argued to be economically small (Jensen and Murphy 1990). Also, the managerial power literature has its starting point in the finding that CEOs are rewarded for non-performance (Bertrand and Mullainathan 2001). Edmans et al. (2017) provide a more comprehensive discussion on this topic.
} 


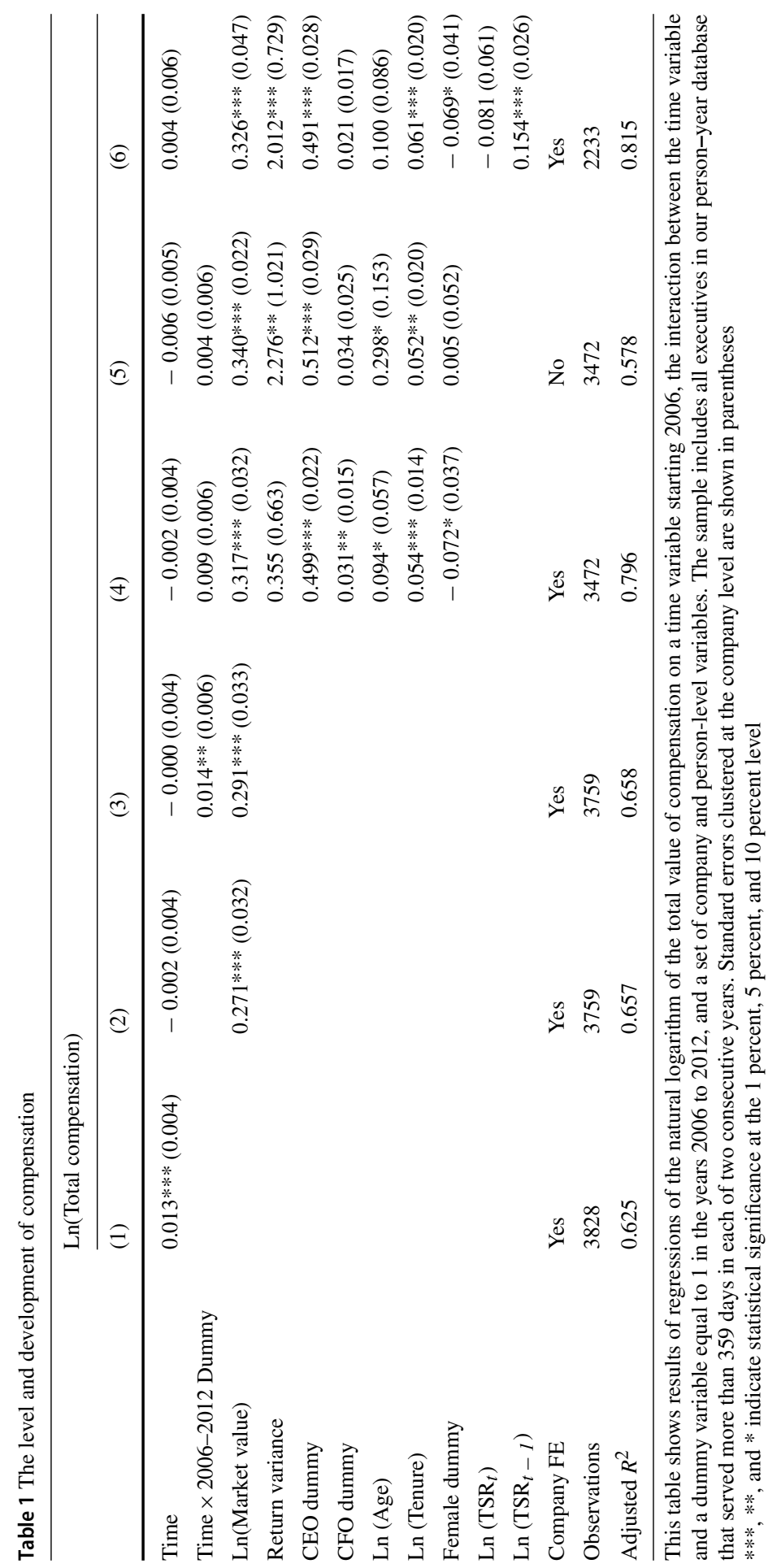


research had been devoted to explanations for the sharp increase in compensation levels between 1980 and 2005, we do not fully understand what drives the differences between growth rates in different countries and decades. Murphy (2013) criticizes that the context of executive compensation including disclosure requirements, tax policies, and the general political climate is largely ignored. Especially Germany has a unique corporate governance structure (Küpper 2006). Cross-country studies can be a promising avenue for future research by allow to integrate contextual and political factors when identifying reasons for the fluctuating paces in compensation growth.

The shareholder value view predicts that executives in larger, more successful, and more risky companies earn more than their colleagues in smaller, less successful, and less risky companies. Prior literature confirms that compensation levels increase in company size (e.g., Murphy 1999; Gabaix and Landier 2008; Frydman and Saks 2010; Gabaix et al. 2014), company success (Murphy 1985; Coughlan and Schmidt 1985; Hall and Liebman 1998), and company risk (Cheng et al. 2015). Our results for German companies provide additional evidence for all three predictions. However, Edmans et al. (2017) finds some evidence that CEO compensation levels are negatively associated with CEO age while we provide strong evidence that executive compensation levels are positively associated with executive age in Germany. Moreover, findings from our database as well as from the US suggest that female executives earn less than their male counterparts (Bertrand and Hallock 2001; Muñoz-Bullón 2010). ${ }^{14}$ Results from the US can partially be explained by the fact that women enter smaller firms (Bertrand and Hallock 2001; Muñoz-Bullón 2010). However, we find that women earn less only when controlling for company-fixed effects while we find an insignificantly positive association when not controlling for company-fixed effects. This suggests that women tend to work for companies that pay higher compensation levels in Germany. The different results regarding age and gender of executives indicate differences in the structure of the market for executive talent and labor. Our database will allow future research to make more in-depth comparisons.

\subsection{The development of the compensation structure}

The media, researchers, and shareholders' associations repeatedly question whether higher compensation levels reflect improved performance of executives and their companies and have called for a higher proportion of variable compensation. Since 2009, the AMBR has required supervisory boards of German companies to ensure that compensation is in line with the economic development of the company. Figure 2 depicts the average composition of annual compensation. The variable compensation decreased from 64 percent in 2006 to 50 percent in 2009, presumably due to the consequences of the financial crisis. Decreasing company performance during these years resulted in lower bonuses for executives. In subsequent years, the share of total variable compensation increased to a peak of 74 percent in 2015 and then slightly decreased in recent years.

\footnotetext{
14 There is some evidence that male executives receive stronger performance-dependent compensation than female executives (Kulich et al. 2011; Edmans et al. 2017).
} 


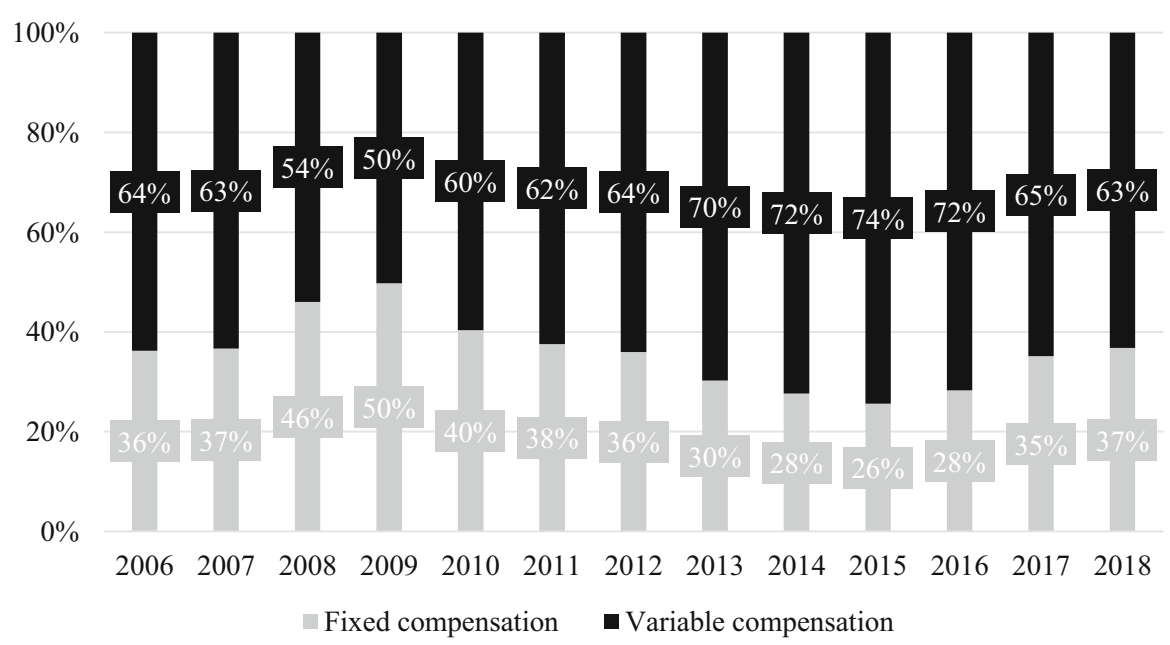

Fig. 2 Structure of total compensation from 2006 to 2018. Values show the share of fixed versus variable compensation, averaged over all companies listed on the DAX or MDAX

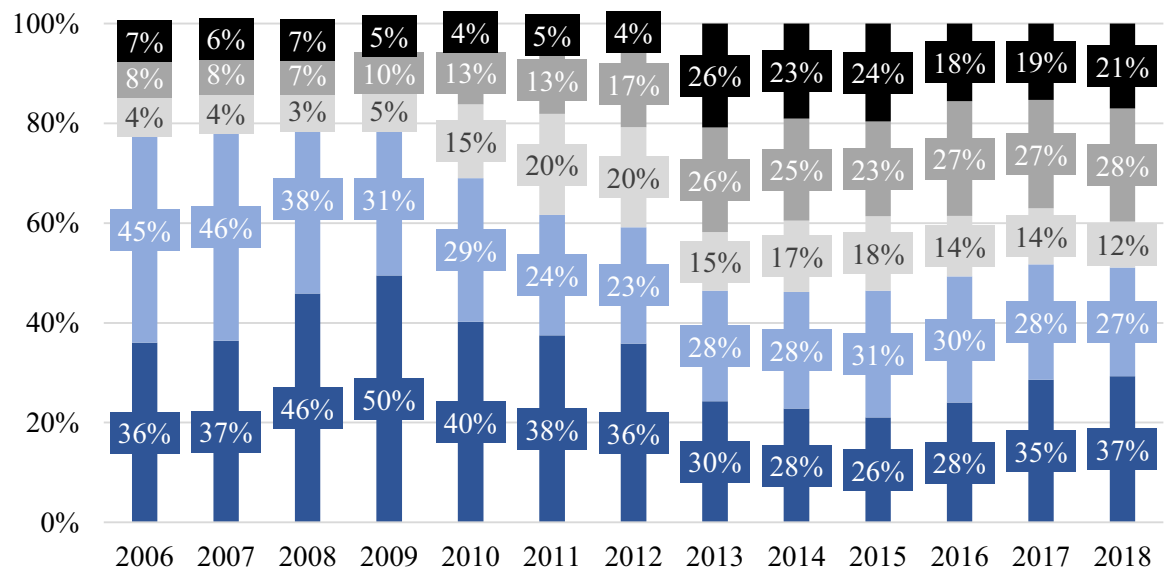

$\square$ Fixed compensation $₫$ One-year bonus $₫$ Multi-year bonus $\backsim$ Stock grants $₫$ Option grants

Fig. 3 Detailed structure of total compensation from 2006 to 2018

The public has not only questioned whether the development of executive compensation reflects economic success but also suspects that the remuneration of executives may be too short-term oriented. In order to deal with this criticism, the German legislator has explicitly stipulated long-term oriented bonus schemes in the AMBR. As shown in Fig. 3, compensation components with a duration of multiple years account for a large part of the relative increase in variable compensation from 2009 to 2013. While one-year bonuses remained rather stable, within a range from 23 to 31 percent, 
the share of stock-based compensation components increased from 15 percent in 2009 to 52 percent in 2018 .

We also test this trend by regressing the natural logarithm of the individual compensation components on a continuous time variable, a proxy for company size, and company dummies. The results in Table 2 show that the growth of fixed compensation is stable while variable compensation components develop dynamically. Fixed compensation increased significantly and at a constant rate from 2006 to 2018 (columns 1 and 2). One-year bonuses decreased significantly from 2006 to 2018, especially in the period 2006 to 2012 (columns 3 and 4). Both multi-year bonuses and total equity grants grew significantly more from 2006 to 2012 than from 2013 to 2018 (columns 6-8). Also, total equity grants increased significantly in both time periods. These findings indicate that the structure of compensation changed significantly from 2006 to 2012 and remained rather stable afterwards.

Overall, current compensation schemes in Germany differ fundamentally from schemes used before the financial crisis. Executives in 2018 earned a higher share of their total compensation from variable compensation components than in 2006. Especially long-term incentive schemes and equity components became more important.

\subsection{The relationship between compensation and company size}

Among the determinants of compensation levels that we examine in Sect. 4.2, company size is one of the most frequently analyzed by theorists and by empiricists. Assignment models suggest that executive compensation levels increase in a company's size as well as in the aggregated size of all companies in an executive's labor market. Many empirical studies provide support for this (e.g., Gabaix and Landier 2008; Frydman and Saks 2010). Our results from Sect. 4.1 and descriptive statistics confirm a strong correlation between compensation levels and company size. The median equity market value of companies in our database increased by 26 percent from EUR 4.653bn to EUR 5.858bn between 2006 and 2018. Figure 4 shows the median share of total equity market value that shareholders spent to compensate all the executives at their company. This share trends downwards from an average of 0.16 percent in the period 2006 to 2012 to an average of 0.11 percent in the period 2013 to 2018 . $^{15}$

Frydman and Saks (2010) study the relationship between executive compensation and company size in a data set from the US spanning the years from 1936 to 2005. They decompose company size into (1) aggregated company size in a particular year (reflecting the size of a typical company in a year), (2) the time-average of a particular company's size (reflecting company-specific factors), and (3) the time- and company-specific component of company size (reflecting idiosyncratic changes that are unrelated to market-wide factors or time-constant factors at the company level). Additionally, they examine whether these relationships change over time. They find

\footnotetext{
15 The Figure also shows the median share of the annual EBIT that shareholders spent to compensate the executives. This share decreased as well from 1.42 percent in 2006 to 0.91 percent in 2018. Göx (2016) conducts similar analyses for companies in the DAX30 and shows that in 1985, shareholders spent 1.15 percent of annual EBIT and 0.14 percent of the market value of equity to compensate all executives.
} 


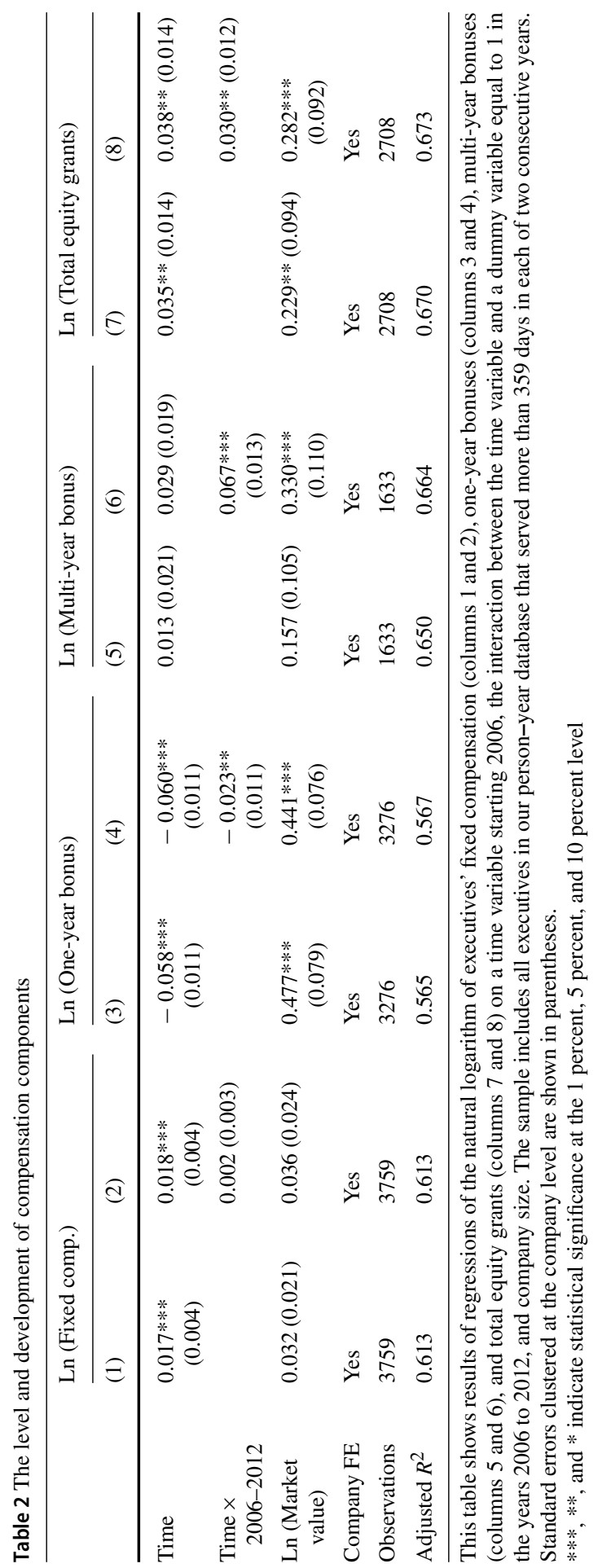




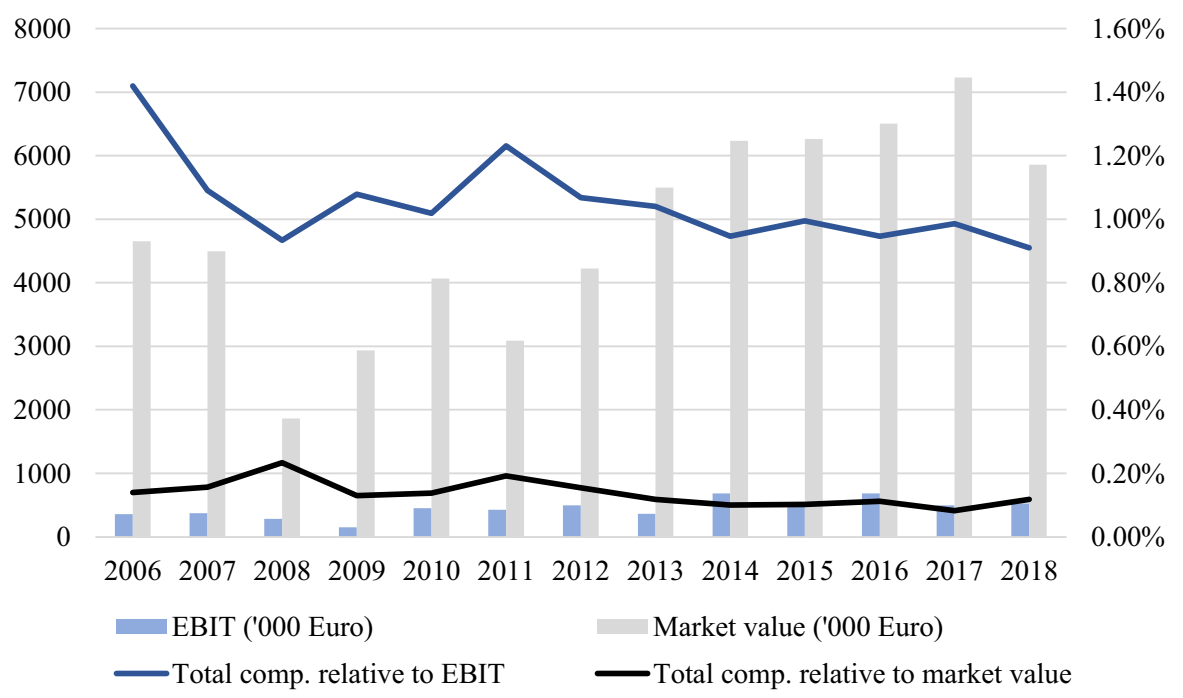

Fig. 4 Total compensation and firm financials from 2006 to 2018

that the idiosyncratic component is a strong predictor for compensation levels throughout the whole period while the aggregated company size is much stronger associated with executive compensation levels between 1976 and 2005 than between 1946 and 1975.

To confirm our descriptive results and to test for a change in the predictive value of (aggregated) company size during the years that our database comprises, we reexamine the model by Frydman and Saks (2010) using our database. In Table 3, we provide results decomposing the correlation of executive compensation and company size into the three components suggested by Frydman and Saks (2010). We measure the size of a company by its market capitalization (columns 1-3) and show results using sales as alternative measure (columns 4-5). Again, we split our data into the periods 2006 to 2012 (columns 2 and 4) and 2013 to 2018 (columns 3 and 5).

Company size has a significantly positive effect on total compensation. The coefficient is about 0.3 and does not change at a statistically significant level over time. Including size as only regressor produces an $R^{2}$ statistic greater than 0.35 , indicating that size is indeed an important predictor of compensation. The company-specific and idiosyncratic component of company size have a significantly positive effect on total compensation. Both coefficients are about 0.3 and do not change significantly across time periods. Hence, there exists a strong cross-sectional relation between company size and executive compensation. To the contrary, the relation between aggregate company size and total compensation changed significantly over time in our sample. ${ }^{16}$ Aggregate company size has a significantly positive effect only in the first period but no significant effect in more recent years. We find similar results when allowing for heterogeneity at the company level (Panel 3) and when allowing for a time trend in

\footnotetext{
16 In untabulated results, we find a significantly negative coefficient of the interaction term between average size and a dummy variable equal to one in the second time period.
} 
Table 3 The relation between compensation and company size

\begin{tabular}{|c|c|c|c|c|c|}
\hline & \multicolumn{3}{|c|}{ Firm Size = Ln (Market value) } & \multicolumn{2}{|c|}{ Firm Size $=$ Ln (Sales) } \\
\hline & $\begin{array}{l}2006-2018 \\
\text { (1) }\end{array}$ & $\begin{array}{l}2006-2012 \\
(2)\end{array}$ & $\begin{array}{l}2013-2018 \\
(3)\end{array}$ & $\begin{array}{l}2006-2012 \\
(4)\end{array}$ & $\begin{array}{l}2013-2018 \\
(5)\end{array}$ \\
\hline \multicolumn{6}{|c|}{ Panel 1: DV = Ln (Total compensation) } \\
\hline Company size & $\begin{array}{r}0.296 * * * \\
(0.021)\end{array}$ & $\begin{array}{r}0.299 * * * \\
(0.022)\end{array}$ & $\begin{array}{r}0.310 * * * \\
(0.026)\end{array}$ & $\begin{array}{r}0.249 * * * \\
(0.020)\end{array}$ & $\begin{array}{r}0.236^{* * * *} \\
(0.020)\end{array}$ \\
\hline Observations & 4194 & 2172 & 2022 & 2185 & 2037 \\
\hline Adjusted $R^{2}$ & 0.414 & 0.442 & 0.385 & 0.367 & 0.362 \\
\hline \multicolumn{6}{|c|}{ Panel 2: Decomposition of company size } \\
\hline $\begin{array}{l}\text { Avg. size in a } \\
\text { year }\end{array}$ & $\begin{array}{r}0.188^{* * * *} \\
(0.046)\end{array}$ & $\begin{array}{r}0.339 * * * \\
(0.064)\end{array}$ & $\begin{array}{r}-0.175 \\
(0.133)\end{array}$ & $0.191(0.222)$ & $\begin{array}{l}0.549 * * \\
(0.239)\end{array}$ \\
\hline $\begin{array}{l}\text { Avg. company } \\
\text { size }\end{array}$ & $\begin{array}{r}0.304 * * * \\
(0.022)\end{array}$ & $\begin{array}{r}0.300 * * * \\
(0.023)\end{array}$ & $\begin{array}{r}0.307 * * * \\
(0.028)\end{array}$ & $\begin{array}{r}0.253 * * * \\
(0.019)\end{array}$ & $\begin{array}{r}0.233^{* * * *} \\
(0.019)\end{array}$ \\
\hline $\begin{array}{l}\text { Size - Comp. } \\
\text { avg. - Year } \\
\text { avg }\end{array}$ & $\begin{array}{r}0.307 * * * \\
(0.041)\end{array}$ & $\begin{array}{r}0.245^{* * *} * \\
(0.060)\end{array}$ & $\begin{array}{r}0.373 * * * \\
(0.084)\end{array}$ & $\begin{array}{r}-0.045 \\
(0.199)\end{array}$ & $\begin{array}{r}0.520 * * * \\
(0.141)\end{array}$ \\
\hline Observations & 4194 & 2172 & 2022 & 2185 & 2037 \\
\hline Adjusted $R^{2}$ & 0.418 & 0.443 & 0.391 & 0.374 & 0.369 \\
\hline \multicolumn{6}{|c|}{ Panel 3: Including company fixed effects } \\
\hline $\begin{array}{l}\text { Avg. size in a } \\
\text { year }\end{array}$ & $\begin{array}{r}0.233^{* * * *} \\
(0.038)\end{array}$ & $\begin{array}{r}0.335^{* * * *} \\
(0.065)\end{array}$ & $0.030(0.109)$ & $\begin{array}{l}0.402 * * \\
\quad(0.164)\end{array}$ & $0.114(0.180)$ \\
\hline $\begin{array}{l}\text { Size - Comp. } \\
\text { avg. - Year } \\
\text { avg }\end{array}$ & $\begin{array}{r}0.276^{* * * *} \\
(0.034)\end{array}$ & $\begin{array}{r}0.298 * * * \\
(0.060)\end{array}$ & $\begin{array}{r}0.319 * * * \\
(0.060)\end{array}$ & $\begin{array}{r}0.349 * * * \\
(0.116)\end{array}$ & $\begin{array}{l}0.229 * * \\
(0.103)\end{array}$ \\
\hline Observations & 4194 & 2172 & 2022 & 2185 & 2037 \\
\hline Adjusted $R^{2}$ & 0.652 & 0.663 & 0.676 & 0.637 & 0.669 \\
\hline \multicolumn{6}{|c|}{ Panel 4: Including time trend } \\
\hline $\begin{array}{l}\text { Avg. size in a } \\
\text { year }\end{array}$ & $\begin{array}{r}0.242 * * * \\
(0.055)\end{array}$ & $\begin{array}{r}0.328^{* * *} * \\
(0.066)\end{array}$ & $0.018(0.129)$ & $\begin{array}{l}0.704 * * \\
\quad(0.292)\end{array}$ & $0.019(0.194)$ \\
\hline $\begin{array}{l}\text { Size - Year } \\
\text { avg }\end{array}$ & $\begin{array}{r}0.275^{* * * *} \\
(0.034)\end{array}$ & $\begin{array}{r}0.309 * * * \\
(0.058)\end{array}$ & $\begin{array}{r}0.319 * * * \\
(0.061)\end{array}$ & $\begin{array}{r}0.339 * * * \\
(0.116)\end{array}$ & $\begin{array}{l}0.280 * * \\
(0.128)\end{array}$ \\
\hline Observations & 4194 & 2172 & 2022 & 2185 & 2037 \\
\hline Adjusted $R^{2}$ & 0.652 & 0.665 & 0.676 & 0.638 & 0.670 \\
\hline \multicolumn{6}{|c|}{ Panel 5: $\mathrm{DV}=\Delta \operatorname{Ln}($ Total compensation $)$} \\
\hline$\Delta$ Avg. of size & $\begin{array}{l}0.150^{* * *} \\
\quad(0.062)\end{array}$ & $\begin{array}{l}0.165^{* *} \\
(0.073)\end{array}$ & $0.093(0.089)$ & $0.508 *(0.294)$ & $\begin{array}{r}-0.233 \\
(0.203)\end{array}$ \\
\hline $\begin{array}{c}\Delta \text { Size }-\Delta \\
\text { Year avg }\end{array}$ & $\begin{array}{r}0.256^{* * * *} \\
(0.043)\end{array}$ & $\begin{array}{r}0.286^{* * * *} \\
(0.058)\end{array}$ & $\begin{array}{l}0.205^{* *} \\
(0.079)\end{array}$ & $\begin{array}{l}0.485^{* *} * \\
\quad(0.191)\end{array}$ & $0.122(0.134)$ \\
\hline Observations & 3553 & 1722 & 1831 & 1732 & 1849 \\
\hline Adjusted $R^{2}$ & 0.031 & 0.043 & 0.013 & 0.018 & 0.008 \\
\hline
\end{tabular}

This table shows results of regressions of total compensation on company size. The dependent variable in Panels 1 to 4 is the natural logarithm of total compensation and it is the yearly change in the natural logarithm of total compensation in Panel 5. Company size is measured by the natural logarithm of a company's market value in columns 1 to 3 and by the natural logarithm of a company's total sales in columns 4 and 5. Company size is decomposed as described in Sect. 4.4. The sample includes all executives in our person-year database that served more than 359 days in a year. Standard errors clustered at the company level are shown in parentheses $* * *, * *$, and $*$ indicate statistical significance at the 1 percent, 5 percent, and 10 percent level 
total compensation (Panel 4). Results of a first-differences approach also show that the effect of aggregate market value becomes smaller in the first time period by about one half while it stays insignificant in the second period (Panel 5). The influence of the idiosyncratic size component continues to be significantly positive in this specification.

Overall, our results suggest a time-consistent and positive association between company size and executive compensation levels. While theory additionally predicts that executives earn higher compensation levels when aggregated company size in their labor market increases, we find this association to fluctuate over time. These findings are in line with the findings by Frydman and Saks (2010) on executives in the US. Whether this contradicts assignment models or whether this may be explained by structural changes in the labor market for executives are still questions to be answered. Suggested solutions postulate that the supply of executive talent or a tendency towards hiring external executives instead of promoting own employees may have affected the labor market for executives (Gabaix and Landier 2008; Edmans et al. 2017). The lack of comparable international data may have hampered cross-country studies. In a notable exception, Gabaix and Landier (2008) find that the "typical" company size in a country can explain about half of the cross-county variation in executive compensation. This lends support for assignment models but also indicates that labor markets for executives are far from being fully integrated across countries. More cross-country studies may help to better understand how properties of the labor market for executives, such as the supply of executive talent or typical career paths of executives, affect compensation levels.

\subsection{The level and development of vertical pay inequality}

In the previous section, we show that executive compensation did not grow faster than companies' sizes and performance levels between 2006 and 2018. However, in many countries, the media and the public still question whether the amounts earned by executives are appropriate relative to the average salary of an employee in the company. The US, the United Kingdom, and some other countries require publicly listed companies to disclose not only the level of CEO compensation but also the CEO pay ratio, the ratio of the $\mathrm{CEO}$ compensation to the median salary of all employees. There is currently no comparable legislation in Germany. However, under IFRS, companies are required to report the total salary and the number of all employees. We use these numbers to calculate the average salary of a company and relate this to the level of CEO compensation.

Figure 5 shows the development of the mean and the median CEO pay ratio in our database between 2006 and 2018. In 2006, the median CEO earned 43 times the average salary in his or her company. This number increased to 53 in 2018. In the same period, the mean pay ratio increased from 53 to 100 with a remarkable increase from 79 in 2017 to 100 in $2018 .{ }^{17}$ Compared to pay ratios in the US, these numbers are moderate. In the US, companies have had to file the ratio of CEO compensation

17 The overall increase in the pay ratio is statistically significant. We regress the natural logarithm of the CEO pay ratio on a continuous time variable and company dummies. The coefficient of the time variable is 0.032 ( $p$ value $=0.002$ when we use standard errors clustered at the company-level). 


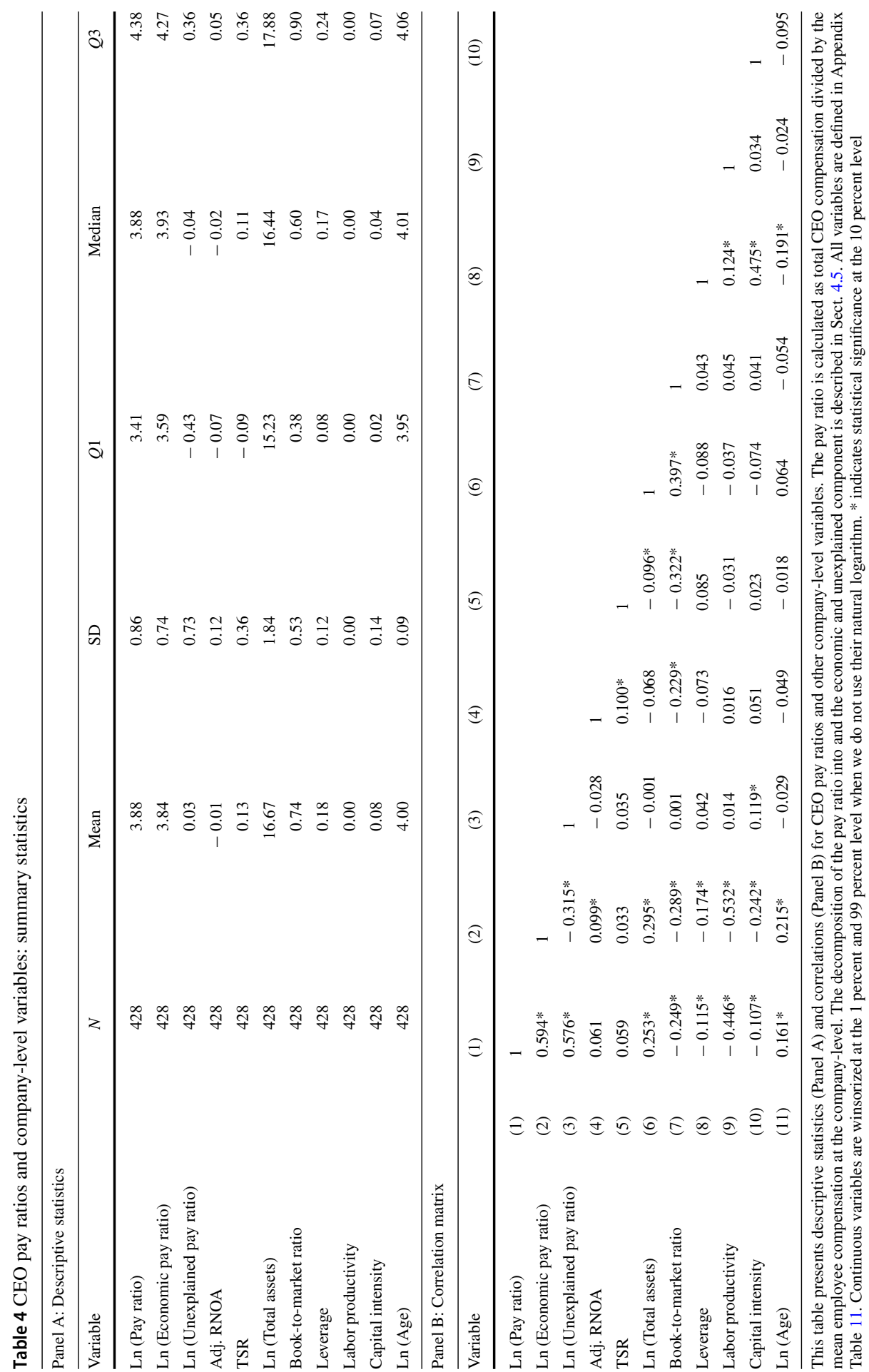




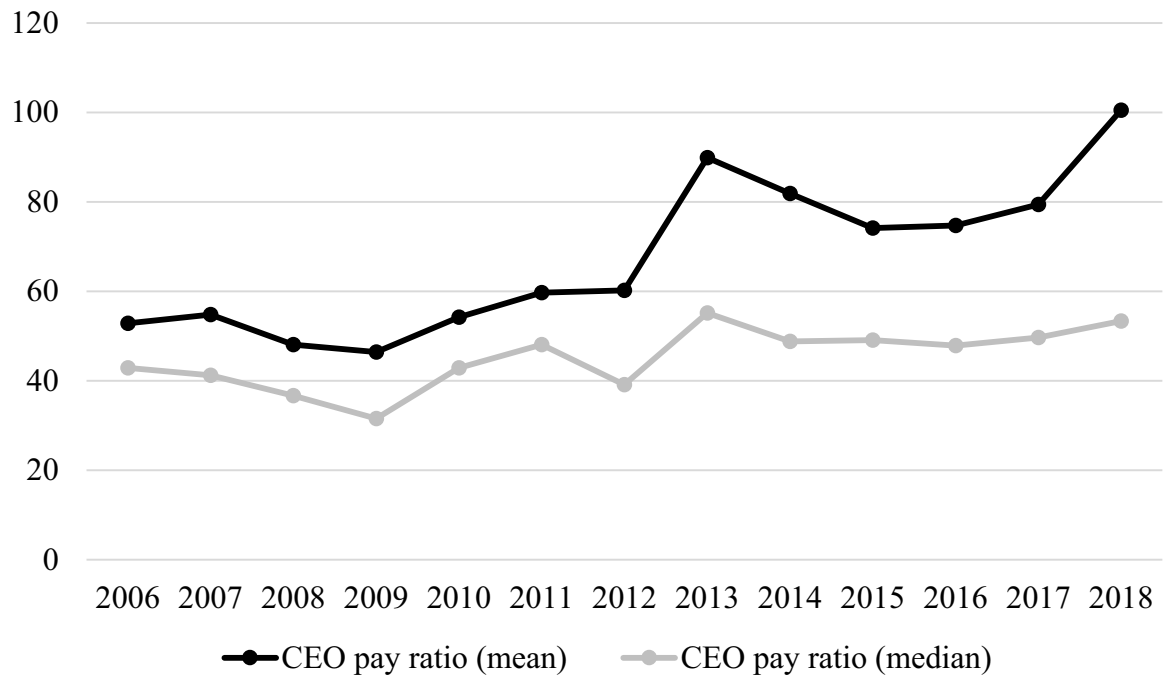

Fig. 5 CEO pay ratio of German companies from 2006 to 2018

and median employee compensation since 2018. During the first year, the mean pay ratio among companies listed in the S\&P 1500 was 197 and the median pay ratio was 96. The highest filed pay ratio was 5,900 while the highest pay ratio calculated from our data in Germany is $1,340 .^{18}$

There are conflicting views of whether high vertical pay inequality within a company is detrimental or beneficial for a company's performance (e.g., Kettenring et al. 2014). Tournament theory suggests that high vertical pay inequality sets strong incentives for employees to provide effort in order to achieve promotion and, hence, can improve company performance (Lazear and Rosen 1981; Green and Stokey 1983). In contrast, equity theory suggests that high pay inequality within a company causes feelings of deprivation and leads employees to decrease effort and collaboration and, hence, can harm company performance (Adams 1965; Cowherd and Levine 1992). Empirical evidence on the relationship between company performance and CEO pay ratios is mixed. Some studies find a positive relationship between pay ratios and companies' performance (Faleye et al. 2013; Banker et al. 2016; Cheng et al. 2017) while others find a negative relationship (Shin et al. 2015).

Rouen (2020) suggests that only inequality that cannot be explained by economic factors-such as the size of the company-deprives employees and harms companies' performance. He shows that future company performance is negatively related to pay inequality not traceable to economic factors known to influence CEO compensation or other employees' compensation. Simultaneously, he finds that future company performance is positively related to pay inequality tracible to the respective economic factors. We test whether Rouen's results hold for Germany companies as

\footnotetext{
18 To calculate CEO pay ratios in Germany, we use average salaries while the CEO pay ratios disclosed by companies in the Unites States are based on the median employee salary.
} 
well. First, we re-estimate his model for the explained CEO compensation ${ }^{19}$ and we estimate the expected average employee compensation as the year-industry average of the mean employee compensation. We calculate the economic pay ratio by dividing the explained CEO compensation by the expected average employee compensation. We calculate the unexplained pay ratio as difference between the actual and the economic pay ratio. Second, we regress future company performance measured by the adjusted return on net operating assets (adj. RNOA) on the natural logarithm of the CEO pay ratio, the $\mathrm{CEO}$ pay ratio decomposed into its economic and unexplained components, and a vector of control variables.

Table 4 shows descriptive statistics and Table 5 shows results of the regression analysis. Our findings are in line with the evidence presented by Rouen (2020). Future company performance is not significantly associated with the overall pay ratio (column 1). However, it is positively associated with the economic pay ratio and it is negatively associated with the unexplained pay ratio (columns 2-5). Thus, US based evidence on the relation between vertical pay inequality and company performance generalizes to the Germany setting. This is notable because the level of vertical pay inequality is distinctly higher in the US. One interpretation is that cross-country variation in the distribution of the CEO pay ratio-for instance due to cultural differences that influence the perception and judgment of pay inequality (Shin et al. 2015) — does not enhance arguments of either tournament theory or equity theory at the cost of attenuating the other. Instead, the position of a company in the within-country distribution of its economically explainable (and unexplainable) CEO pay ratio appears to be associated with the future performance of the company.

\section{Conclusion}

With this study, we provide a database containing recent data on executive compensation in Germany. Understanding the corporate governance role of executive compensation and how it affects company outcomes continuous to be interesting field of research. Especially recent evidence for countries other than the US may help us understand the influence of country-specific factors on compensation and thereby reconcile open questions in this research area. For this purpose, we address challenges and ambiguities related to the collection of executive compensation data in Germany and provide a database that is structured very similarly to ExecuComp. We also provide evidence on the development of executive compensation between 2006 and 2018 in Germany and test important associations between compensation and company level variables as well as executive level variables. Thereby, we show the application potential of our database.

We can generalize some findings of earlier studies on executive compensation in the US, thereby corroborating the underlying theories. For instance, we show that the

\footnotetext{
19 Specifically, we regress total CEO compensation on a company's industry-adjusted return on assets, its total shareholder return of the current and the previous year, its logarithm of total assets, leverage, book-tomarket ratio, return variance, a dummy variable indicating whether the company made a loss, the logarithm of an executive's age and tenure, and Fama-French 12-industry dummies. We do not include the variance of the return on assets. All variables are defined in Appendix Table 11. See Eq. (2) of Rouen (2020) for details.
} 


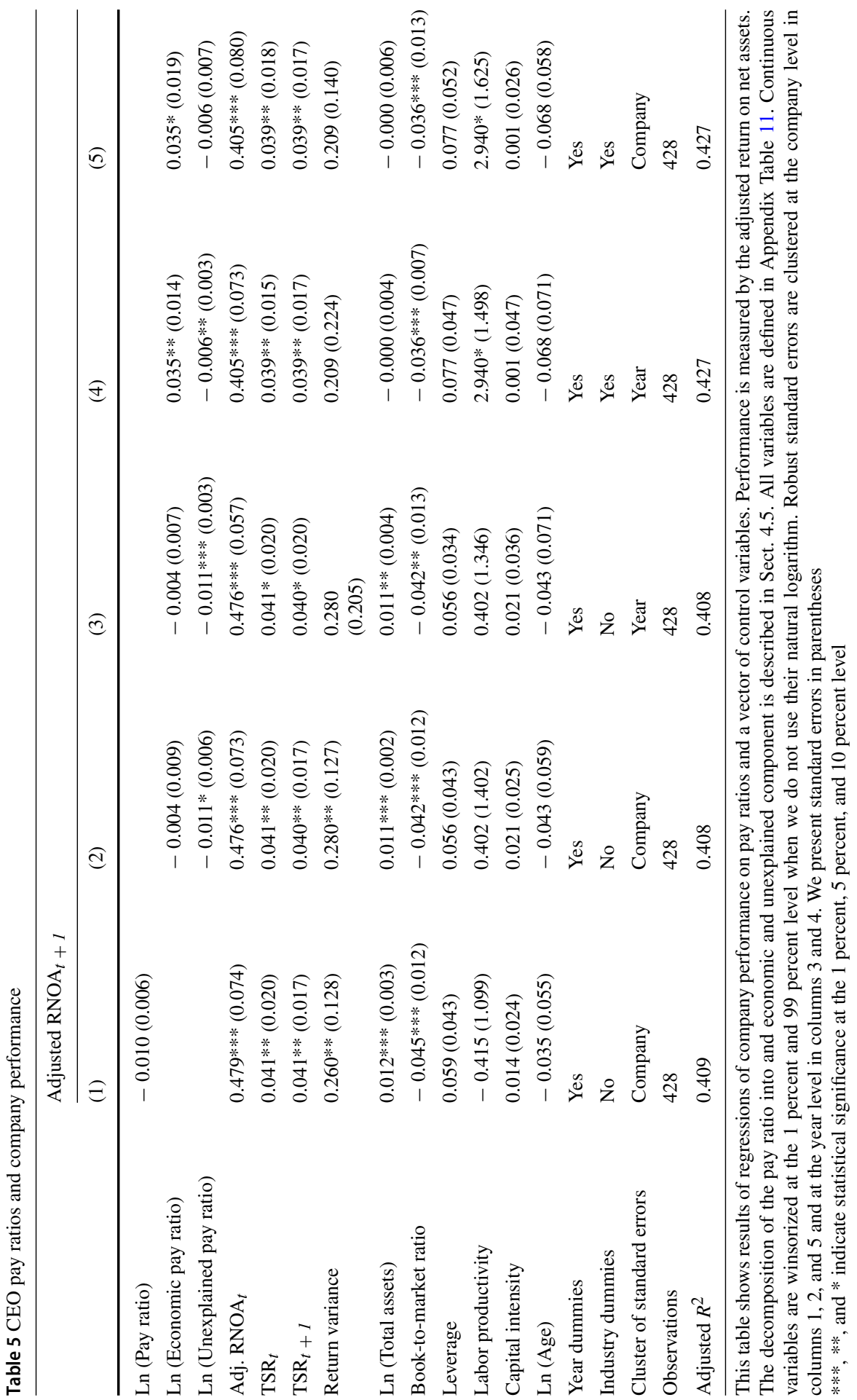


association between aggregate company size and total compensation is highly specific to the period under consideration. We also provide evidence for arguments of both tournament theory and equity theory that influence the effects of vertical pay inequality. Additionally, we find some differences between the US and Germany that provide an opportunity for future research. For example, the age of executives is positively associated with their compensation in Germany. We hope that our findings stimulate international research on executive compensation and that our database facilitates this research. A better understanding of the antecedents and consequences of executive compensation and its interplay with the cultural, legal, and institutional environment may help to design better compensation systems that are not only aligned with organizational but possibly also with societal demand.

Acknowledgements We thank two anonymous referees and Christian Hofmann (editor) for helpful comments and suggestions. Open Access funding provided by Projekt DEAL.

Open Access This article is licensed under a Creative Commons Attribution 4.0 International License, which permits use, sharing, adaptation, distribution and reproduction in any medium or format, as long as you give appropriate credit to the original author(s) and the source, provide a link to the Creative Commons licence, and indicate if changes were made. The images or other third party material in this article are included in the article's Creative Commons licence, unless indicated otherwise in a credit line to the material. If material is not included in the article's Creative Commons licence and your intended use is not permitted by statutory regulation or exceeds the permitted use, you will need to obtain permission directly from the copyright holder. To view a copy of this licence, visit http://creativecommons.org/licenses/by/4.0/.

\section{Appendix}

See appendix Tables 6, 7, 8, 9, 10, 11 .

Table 6 Template on granted compensation by the Code

\begin{tabular}{|c|c|c|c|c|c|c|c|c|}
\hline \multirow[t]{4}{*}{ Benefits granted } & \multirow{2}{*}{\multicolumn{4}{|c|}{$\begin{array}{l}\text { Executive name } \\
\text { Position }\end{array}$}} & \multicolumn{4}{|c|}{ Executive name } \\
\hline & & & & & \multicolumn{4}{|c|}{ Position } \\
\hline & \multicolumn{4}{|c|}{ Date of appointment/retirement } & \multicolumn{4}{|c|}{ Date of appointment/retirement } \\
\hline & $n-1$ & $n$ & $n(\min )$ & $n(\max )$ & $n-1$ & $n$ & $n(\min )$ & $n(\max )$ \\
\hline \multicolumn{9}{|l|}{ Fixed remuneration } \\
\hline \multicolumn{9}{|l|}{ Fringe benefits } \\
\hline \multicolumn{9}{|l|}{ Sum } \\
\hline \multicolumn{9}{|l|}{ One-year variable remuneration } \\
\hline \multicolumn{9}{|l|}{ Mutli-year variable remuneration } \\
\hline \multicolumn{9}{|l|}{ Multi-year plan 1 (plan term) } \\
\hline \multicolumn{9}{|l|}{ Multi-year plan 2 (plan term) } \\
\hline \multicolumn{9}{|l|}{$\cdots$} \\
\hline \multicolumn{9}{|l|}{ Sum } \\
\hline \multicolumn{9}{|l|}{ Pension expense } \\
\hline Total remuneration & & & & & & & & \\
\hline
\end{tabular}

(Adjusted, based on the German Corporate Governance Code, as of February 2017) 
Table 7 Template on paid out compensation by the Code

\begin{tabular}{|c|c|c|c|c|}
\hline \multirow[t]{4}{*}{ Benefits received } & \multirow{2}{*}{$\frac{\text { Name }}{\text { Position }}$} & \multirow{2}{*}{$\frac{\text { Name }}{\text { Position }}$} & \multirow{2}{*}{$\frac{\text { Name }}{\text { Position }}$} & \multirow{2}{*}{$\frac{\text { Name }}{\text { Position }}$} \\
\hline & & & & \\
\hline & $\begin{array}{l}\text { Entry/exit } \\
\text { date }\end{array}$ & $\begin{array}{l}\text { Entry/exit } \\
\text { date }\end{array}$ & $\begin{array}{l}\text { Entry/exit } \\
\text { date }\end{array}$ & $\begin{array}{l}\text { Entry/exit } \\
\text { date }\end{array}$ \\
\hline & $n-1$ & $n-1$ & $n-1$ & $n-1$ \\
\hline
\end{tabular}

Fixed remuneration

Fringe benefits

Sum

One-year variable remuneration

Mutli-year variable remuneration

Multi-year plan 1 (plan term)

Multi-year plan 2 (plan term)

...

Sum

Pension expense

Total remuneration

(Adjusted, based on the German Corporate Governance Code, as of February 2017)

Table 8 Definition of person-year variables in database and comparison to ExecuComp

Panel 1: Definition of variables

\begin{tabular}{|c|c|}
\hline Variable & Definition \\
\hline \multicolumn{2}{|l|}{ General variables } \\
\hline Company_person_id & Unique identifier for each company/executive combination \\
\hline Year & $\begin{array}{l}\text { Year of the data, specified as year when the fiscal year ends. Thus, } \\
\text { fiscal years ending from 01/01/06 to } 12 / 31 / 06 \text { are part of the } \\
2006 \text { data year }\end{array}$ \\
\hline Isin & ISIN of the company \\
\hline Company_shortname & Short name of the company. Serves as unique identifier \\
\hline Company_name & Full name of the company \\
\hline Exec_id & Unique identifier for each executive \\
\hline Exec_fullname & Full name of the executive, including academic titles \\
\hline Days & $\begin{array}{l}\text { Number of days served by the executive on the executive board } \\
\text { during the fiscal year }\end{array}$ \\
\hline Ceo_flag_eoy & $\begin{array}{l}\text { Dummy variable; } 1 \text { if the executive served as CEO at the end of } \\
\text { the fiscal year }\end{array}$ \\
\hline Cfo_flag_eoy & $\begin{array}{l}\text { Dummy variable; } 1 \text { if the executive served as CFO at the end of } \\
\text { the fiscal year }\end{array}$ \\
\hline Date_begin_ceo & $\begin{array}{l}\text { Date in the fiscal year when the executive started his or her } \\
\text { assignment as CEO. Equals the fiscal year start date if the CEO } \\
\text { continued his or her assignment as CEO from the previous year }\end{array}$ \\
\hline
\end{tabular}


Table 8 continued

Panel 1: Definition of variables

\begin{tabular}{ll}
\hline Variable & Definition \\
\hline Date_end_ceo & $\begin{array}{c}\text { Date in the fiscal year when the executive left his or her } \\
\text { assignment as CEO. Equals the fiscal year end date if the CEO } \\
\text { continued his or her assignment as CEO in the following year } \\
\text { Date in the fiscal year when the executive started his or her } \\
\text { assignment as CFO. Equals the fiscal year start date if the CFO } \\
\text { continued his or her assignment as CFO from the previous year } \\
\text { Date in the fiscal year when the executive left his or her } \\
\text { assignment as CFO. Equals the fiscal year end date if the CFO } \\
\text { continued his or her assignment as CFO in the following year }\end{array}$
\end{tabular}

Compensation variables

All compensation variables of this data table are reported at the executive level, in thousands of Euros

Salary

Other_annual_comp

One_year_bonus

Multi_year_bonus

Multi_year_bonus_grants

Multi_year_bonus_payout

Total_equity_grants

Stock_grants

Option_grants

Pension

One_time_payment

Total_comp
Value of the base salary earned. The value is based on the realization principle for 2006 to 2013; the compensation paid, for 2014 to 2018

Value of other annual compensation paid. Includes items such as fringe benefits and personal benefits. The value is based on the realization principle for 2006 to 2013; the compensation paid, for 2014 to 2018

Value of a one-year bonus earned, to be paid in the following year. The value is based on the realization principle for 2006 to 2013; the compensation paid, for 2014 to 2018

Value of a non-equity multi-year bonus earned. Does not include multi-year bonuses that are paid in stock (options). The value is based on the realization principle for 2006 to 2013; the compensation paid for 2014 to 2018

Value of a non-equity multi-year bonus granted. Does not include multi-year bonuses that are paid out in stock (options). The variable is available starting 2014

Value of a non-equity multi-year bonus paid. Does not include multi-year bonuses that are paid in stock (options). The variable is available starting 2014

Total value of equity compensation. Calculated as sum of stock_grants and option_grants

The granting-date fair value of all stock awards as reported by the company according to GCC $\$ 285$ and 314 . Includes multi-year bonuses that are paid in stock

The granting-date fair value of all option awards as reported by the company according to GCC $\$ 285$ and 314 . Includes multi-year bonuses that are paid in options

Value of additions to pension accruals

Value of individual one-time payments paid. Includes items such as signing bonuses and severance pay

Total value of compensation. Calculated as sum total of salary, other_annual, one_year_bonus, multi_year_bonus, stock_grants, and option_grants 
Table 8 continued

Panel 1: Definition of variables

\begin{tabular}{ll}
\hline Variable & Definition \\
\hline Total_comp_pens_and_one_time & $\begin{array}{r}\text { The total value of compensation. Calculated as sum total of salary, } \\
\text { other_annual, one_year_bonus, multi_year_bonus, stock_grants, } \\
\text { option_grants, one_time_payment, and pensions }\end{array}$ \\
\hline
\end{tabular}

Panel 2: Comparison of compensation variables in our database and ExecuComp

\begin{tabular}{|c|c|c|}
\hline Our database & ExecuComp & Note \\
\hline Salary & SALARY & - \\
\hline Other_annual_comp & ALLOTHPD & - \\
\hline One_year_bonus & BONUS & - \\
\hline Multi_year_bonus & NONEQ_INCENT & $\begin{array}{l}\text { Until 2006, ExecuComp reports } \\
\text { the payout of long-term } \\
\text { incentive plans in the variable } \\
\text { LTIP. For the years later than } \\
\text { 2006, ExecuComp follows the } \\
\text { realization principle and } \\
\text { reports amounts earned from } \\
\text { long-term, non-equity } \\
\text { incentive plans in the variable } \\
\text { NONEQ_INCENT. In } \\
\text { comparison, we report the } \\
\text { realized compensation for the } \\
\text { years from } 2006 \text { to } 2013 \text { and } \\
\text { the paid compensation for the } \\
\text { years from } 2014 \text { to the } \\
\text { present in the variable } \\
\text { Multi_year_bonus (see } \\
\text { Sect. } 3.2 .1 \text { for details) }\end{array}$ \\
\hline Multi_year_bonus_grants & - & See Multi_year_bonus \\
\hline Multi_year_bonus_payout & - & $\begin{array}{l}\text { See Multi_year_bonus. Until } \\
\text { 2006, ExecuComp reports the } \\
\text { payout of long-term incentive } \\
\text { plans in the variable LTIP }\end{array}$ \\
\hline Total_equity_grants & - & - \\
\hline Stock_grants & STOCK_AWARDS_FV & - \\
\hline Option_grants & OPTION_AWARDS_FV & - \\
\hline Pension & PENSION_CHG & $\begin{array}{l}\text { The numbers should not be } \\
\text { compared without careful } \\
\text { consideration because the } \\
\text { pension system in the US } \\
\text { differs from the system in } \\
\text { Germany }\end{array}$ \\
\hline One_time_payment & - & $\begin{array}{l}\text { ExecuComp does not report } \\
\text { one-time payments separately } \\
\text { but includes them in the } \\
\text { variable OTHCOMP }\end{array}$ \\
\hline Total_comp & $\begin{array}{l}\text { TOTAL_ALT1 - } \\
\text { PENSION_CHG }\end{array}$ & \\
\hline
\end{tabular}


Table 8 continued

Panel 2: Comparison of compensation variables in our database and ExecuComp

\begin{tabular}{llc}
\hline Our database & ExecuComp & Note \\
\hline $\begin{array}{l}\text { Total_comp_pens_and_ } \\
\text { one_time }\end{array}$ & TOTAL_ALT1 & $\begin{array}{c}\text { The variable includes pensions, } \\
\text { which differ between } \\
\text { Germany and the US }\end{array}$ \\
\hline
\end{tabular}

Table 9 Definition of company-year variables in database

\begin{tabular}{|c|c|}
\hline Variable & Definition \\
\hline \multicolumn{2}{|l|}{ General variables } \\
\hline Isin & ISIN of the company \\
\hline Year & $\begin{array}{l}\text { Year of the data. Specified as year of the fiscal year end. Thus, fiscal } \\
\text { years ending from } 01 / 01 / 06 \text { to } 12 / 31 / 06 \text { are part of the } 2006 \text { data year }\end{array}$ \\
\hline Company_shortname & Short name of the company. Serves as unique identifier \\
\hline Company_name & Full name of the company \\
\hline Opting_out & $\begin{array}{l}\text { Dummy variable; } 1 \text { if the company opted out of disclosing the } \\
\text { compensation of executives at the individual level in the indicated fiscal } \\
\text { year }\end{array}$ \\
\hline N_executives & Number of executives active on the board during the fiscal year \\
\hline Days_bt & $\begin{array}{l}\text { Total number (i.e., sum) of days served by all executives on the board } \\
\text { during the fiscal year }\end{array}$ \\
\hline Fy_begin & Beginning date of the fiscal year \\
\hline Fy_end & Ending date of the fiscal year \\
\hline Index_listing & Categorical variable indicating the stock index the company is listed on \\
\hline \multicolumn{2}{|l|}{ Compensation variables } \\
\hline \multicolumn{2}{|c|}{$\begin{array}{l}\text { All compensation variables of this data table are reported as total value of all executives serving on the board, in } \\
\text { thousands of Euros. Variables are defined in more detail in Appendix Table } 8\end{array}$} \\
\hline Salary_bt & Total value of the base salary earned \\
\hline Other_annual_comp_bt & Total value of other annual compensation paid \\
\hline One_year_bonus_bt & Total value of a one-year bonus earned, to be paid in the following year \\
\hline Multi_year_bonus_bt & Value of a non-equity multi-year bonus earned \\
\hline Multi_year_bonus_grants_bt & Total value of a non-equity multi-year bonus granted \\
\hline Multi_year_bonus_payout_bt & Total value of a non-equity multi-year bonus paid \\
\hline Total_equity_grants_bt & $\begin{array}{l}\text { Total value of equity compensation of all executives. Calculated as sum } \\
\text { of stock_grants and option_grants }\end{array}$ \\
\hline Stock_grants_bt & Fair value of all stock awards \\
\hline Option_grants_bt & Fair value of all options awards \\
\hline Pension_bt & Total value of additions to pension accruals \\
\hline One_time_payment_bt & Total value of one-time payments paid \\
\hline Total_comp_bt & $\begin{array}{l}\text { Total value of compensation. Calculated as board totals of salary, } \\
\text { other_annual, one_year_bonus, multi_year_bonus, stock_grants, and } \\
\text { option_grants }\end{array}$ \\
\hline Total_comp_pens_and_one_time_bt & $\begin{array}{l}\text { Total value of compensation. Calculated as board totals of salary, } \\
\text { other_annual, one_year_bonus, multi_year_bonus, stock_grants, } \\
\text { option_grants, one_time_payment, and pensions }\end{array}$ \\
\hline
\end{tabular}


Table 10 Definition of company-person variables in database

\begin{tabular}{|c|c|}
\hline Variable & Definition \\
\hline Company_person_id & Unique identifier for each company/executive combination \\
\hline ISIN & ISIN of the company \\
\hline Company_shortname & Short name of the company. Serves as unique identifier \\
\hline Exec_id & Unique identifier of the executive \\
\hline Exec_academic_title & Academic title of the executive \\
\hline Exec_firstname & First name of the executive \\
\hline Exec_lastname & Last name of the executive \\
\hline Exec_fullname & Full name of the executive including academic titles \\
\hline Gender & Gender of the executive \\
\hline Nationality & Nationality of the executive \\
\hline Date_of_birth & Date of birth of the executive. January 1 st if only the year is known \\
\hline Company_entry_date & Date when the executive first entered the company \\
\hline Board_entry_date & Date when the executive first entered the board of the company \\
\hline Board_exit_date & Date when the executive exited the board of the company \\
\hline Board_entry_date_private_co & $\begin{array}{l}\text { Date when the executive first entered the board of the non-listed } \\
\text { company }\end{array}$ \\
\hline Board_exit_date_private_co & Date when the executive exited the board of the non-listed company \\
\hline Company_entry_date2 & Date when the executive entered the company for the second time \\
\hline Board_entry_date2 & $\begin{array}{l}\text { Date when the executive entered the board of the company for the } \\
\text { second time. Note that the second exit date can be inferred from the } \\
\text { days variable in the Person_year data table (i.e., days }=0 \text { ) }\end{array}$ \\
\hline
\end{tabular}

Table 11 Variable definitions

\begin{tabular}{ll}
\hline Variable & Definition \\
\hline Time & Continuous time variable starting 2006 \\
2006-2012 Dummy & Dummy variable; 1 in the years 2006 to 2012 \\
Market value & Market capitalization, from Worldscope \\
Return variance & Rolling 60-month standard deviation of total shareholder return \\
CEO dummy & Dummy variable, 1 if the executive served as CEO at the end of the fiscal year \\
CFO dummy & Dummy variable, 1 if the executive served as CFO at the end of the fiscal year \\
Age & Age of the executive \\
Tenure & Tenure at the company of the executive \\
Female dummy & Dummy variable, 1 if the executive is female \\
Sales & Total sales, from Worldscope \\
Avg. size in a year & Mean size of all companies in the sample in a year, from Worldscope \\
Avg. company size & Mean size of the company across all years, from Worldscope \\
Pay ratio & Total CEO compensation/mean employee compensation \\
Economic pay ratio & Explained total CEO compensation/explained mean employee compensation; \\
& explained compensation is calculated as described in Sect. 4.5 \\
\hline
\end{tabular}


Table 11 continued

\begin{tabular}{ll}
\hline Variable & Definition \\
\hline Unexplained pay ratio & $\begin{array}{l}\text { Pay ratio-economic pay ratio } \\
\text { Net income/[(total assets - total cash) - total liabilities }- \text { total debt)] - mean } \\
\text { Fdj. RNOA }\end{array}$ \\
$\begin{array}{l}\text { Total shareholder return, from Datastream } \\
\text { TSR }\end{array}$ & $\begin{array}{l}\text { Total assets, from Worldscope } \\
\text { Total assets }\end{array}$ \\
Book-to-market ratio & Book-to-market ratio, from Worldscope \\
Leverage & Long-term debt/total assets, from Worldscope \\
Labor productivity & Total sales/total employees, from Worldscope \\
Capital intensity & Capital expenditures/total sales, from Worldscope \\
\hline
\end{tabular}

\section{References}

Adams JS (1965) Inequity in social exchange. Adv Exp Soc Psychol 2:267-299

Aggarwal RK, Samwick AA (1999) The other side of the trade-off: the impact of risk on executive compensation. J Political Econ 107(1):65-105

De Angelis D, Grinstein Y (2014) Performance terms in CEO compensation contracts. Rev Financ 19(2):619-651

Armstrong CS, Vashishtha R (2012) Executive stock options, differential risk-taking incentives, and firm value. J Financ Econ 104(1):70-88

Banker RD, Bu D, Mehta MN (2016) Pay gap and performance in China. Abacus 52(3):501-531

Bebchuk LA, Fried JM (2003) Executive compensation as an agency problem. J Econ Perspect 17(3):71-92

Bebchuk LA, Fried JM (2004) Pay without performance: the unfulfilled promise of executive compensation. Harvard University Press, Cambridge

Bebchuk L, Grinstein Y (2005) The Growth of Executive Pay. Oxf Rev Econ Policy 21(2):283-303

Bebchuk LA, Fried JM, Walker DI (2002) Managerial power and rent extraction in the design of executive compensation. Univ Chic Law Rev 69:751-846

Bertrand M, Hallock KF (2001) The gender gap in top corporate jobs. ILR Rev 55(1):3-21

Bertrand M, Mullainathan S (2001) Are CEOs rewarded for luck? The ones without principals are. Q J Econ 116(3):901-932

Bolton P, Mehran H, Shapiro J (2015) Executive compensation and risk taking. Rev Financ 19(6):2139-2181

Cassell CA, Huang SX, Sanchez JM, Stuart MD (2012) Seeking safety: the relation between CEO inside debt holdings and the riskiness of firm investment andfinancial policies. J Financ Econ 103(3):588-610

Cheng IH, Hong H, Scheinkman JA (2015) Yesterday's heroes: compensation and risk at financial firms. J Financ 70(2):839-879

Cheng Q, Ranasinghe T Zhao S (2017) Do high CEO pay ratios destroy firm value? Robert H. Smith School Research Paper No RHS 2861680

Conyon MJ, Murphy KJ (2000) The prince and the pauper? CEO pay in the United States and United Kingdom. Econ J 110(467):640-671

Conyon MJ, Schwalbach J (2000) European differences in executive pay and corporate governance. Zeitschrift für Betriebswirtschaft, Ergänzungsheft 1:97-114

Conyon MJ, Core JE, Guay WR (2011) Are US CEOs paid more than UK CEOs? Inferences from riskadjusted pay. Rev Financ Stud 24(2):402-438

Correa R, Lel U (2016) Say on pay laws, executive compensation, pay slice, and firm valuation around the world. J Financ Econ 122(3):500-520

Coughlan AT, Schmidt RM (1985) Executive compensation, management turnover, and firm performance: an empirical investigation. J Acc Econ 7(1-3):43-66

Cowherd DM, Levine DI (1992) Product quality and pay equity between lower-level employees and top management: an investigation of distributive justicetheory. Administrative Sci Q 37:302-320 
Döscher T, Friedl G (2011) Corporate governance, stakeholder power, and executive compensation. OR Spectr 33(2):309-331

Edmans A, Gabaix X (2016) Executive compensation: a modern primer. J Econ Lit 54(4):1232-1287

Edmans A, Gabaix X, Jenter D (2017) Executive compensation: a survey of theory and evidence. Handbook Econ Corp Gov 1:383-539

Faleye O, Reis E, Venkateswaran A (2013) The determinants and effects of CEO-employee pay ratios. J Bank Financ 37(8):3258-3272

Fernandes N, Ferreira MA, Matos P, Murphy KJ (2013) Are U.S. CEOs paid more? New international evidence. Rev Financ Stud 26(2):323-367

Flammer C, Bansal P (2017) Does a long-term orientation create value? Evidence from a regression discontinuity. Strateg Manag J 38(9):1827-1847

Friedl G (2012) Werden Vorstände großer Aktiengesellschaften richtig vergütet? In: Botzenhart C, Burtscheidt A (eds) Gesellschaftliche Relevanz von Wissenschaft und Forschung. Ein interdisziplinärer Diskurs. Verlag Ferdinand Schöningh, Paderborn, pp 57-82

Friedl G, Hölz C, Beck D, Neumayr L, Stoll C (2019) Studie zur Vergütung der Vorstände in den DAX- und MDAX-Unternehmen im Geschäftsjahr 2018. White Paper, Available at the website of the Deutsche Schutzvereinigung für Wertpapierbeseitz e.V.

Frydman C (2019) Rising through the ranks: the evolution of the market for corporate executives. Manage Sci 65(11):1936-2003

Frydman C, Jenter D (2010) CEO compensation. Annual Rev Financ Econ 2(1):75-102

Frydman C, Saks RE (2010) Executive compensation: a new view from a long-term perspective, 1936-2005. Revf Financ Stud 23(5):2099-2138

Gabaix X, Landier A (2008) Why has CEO pay increased so much? Q J Econ 123(1):49-100

Gabaix X, Landier A, Sauvagnat J (2014) CEO pay and firm size: an update after the crisis. Econ J 124(574):40-59

Gopalan R, Milbourn T, Song F (2010) Strategic flexibility and the optimality of pay for sector performance. Rev Financ Stud 23(5):2060-2098

Gopalan R, Milbourn T, Song F, Thakor AV (2014) Duration of executive compensation. J Financ 69(6):2777-2817

Gopalan R, Huang S, Maharjan J (2016) The role of deferred pay in retaining managerial talent. Working Paper, available at SSRN 2439330

Göx RF (2016) Wachstum und Höhe von Managementvergütungen. Perspektiven der Wirtschaftspolitik 17(4):311-334

Green JR, Stokey NL (1983) A comparison of tournaments and contracts. J Political Econ 91(3):349-364

Guay WR (1999) The sensitivity of CEO wealth to equity risk: an analysis of the magnitude and determinants. J Financ Econ 53(1):43-71

Hall BJ, Liebman JB (1998) Are CEOs really paid like bureaucrats? Q J Econ 113(3):653-691

Hall BJ, Murphy KJ (2002) Stock options for undiversified executives. J Account Econ 33(1):3-42

Hartzell JC, Starks LT (2003) Institutional investors and executive compensation. J Financ 58(6):2351-2374

Hitz JM, Müller-Bloch S (2015) Market reactions to the regulation of executive compensation. Eur Account Rev 24(4):659-684

Holmström B (1979) Moral hazard and observability. Bell J Econ 10(1):74-91

Holmström B (1982) Moral hazard in teams. Bell J Econ 13(2):324-340

Holmström B, Milgrom P (1987) Aggregation and linearity in the provision of intertemporal incentives. Econometrica 55(2):303-328

Jensen MC, Meckling WH (1976) Theory of the firm: managerial behavior, agency costs and ownership structure. J Financ Econ 3(4):305-360

Jensen MC, Murphy KJ (1990) Performance pay and top-management incentives. J Political Econ 98(2):225-264

Kettenring T, Tuschke A, Friedl G (2014) Tournaments, top management team compensation, and the impact of complexity. Schmalenbach Bus Rev 66(2):106-131

Kulich C, Trojanowski G, Ryan MK, Alexander Haslam S, Renneboog LD (2011) Who gets the carrot and who gets the stick? Evidence of gender disparities in executive remuneration. Strateg Manag J 32(3):301-321

Küpper H-U (2006) Unternehmensethik: Hintergründe, Konzepte, Anwendungsbereiche. SchäfferPoeschel, Stuttgart 
Ladika, T., \& Sautner, Z. (2018). Managerial short-termism and investment: evidence from accelerated option vesting. Working paper, available at SSRN 2286789.

Lazear EP, Rosen S (1981) Rank-order tournaments as optimum labor contracts. J Political Econ 89(5):841-864

Lewellen K (2006) Financing decisions when managers are risk averse. J Financ Econ 82(3):551-589

Muñoz-Bullón F (2010) Gender-compensation differences among high-level executives in the United States. Ind Relat J Econ Soc 49(3):346-370

Murphy KJ (1985) Corporate performance and managerial remuneration: an empirical analysis. J Account Econ 7(1):11-42

Murphy KJ (1999) Executive compensation. In: Ashenfelter O, Card D (eds) Handbook of labor economics. Elsevier, Amsterdam, pp 2485-2563

Murphy KJ (2013) Executive compensation: where we are, and how we got there. In: Constantinides G, Harris M, Stulz R (eds) Handbook of the economics of finance. Elsevier, Amsterdam, pp 211-356

Murphy KJ, Zabojnik J (2004) CEO pay and appointments: A market-based explanation for recent trends. Am Econ Rev 94(2):192-196

Murphy KJ, Zabojnik J (2007) Managerial capital and the market for CEOs. Working Paper.

Nam J, Ottoo RE, Thornton JH Jr (2003) The effect of managerial incentives to bear risk on corporate capital structure and R\&D investment. Financ Rev 38(1):77-101

Nickell SJ (1995) The performance of companies: the relationship between the external environment, management strategies and corporate performance. Basil Blackwell, Oxford

Peng R, Yin D (2019) Executive labor market incentives and earnings management. Working Paper

Rapp MS, Wolff M (2010) Determinanten der Vorstandsvergütung: Eine empirische Untersuchung der deutschen Prime-Standard-Unternehmen. Zeitschrift für Betriebswirtschaft 80(10):1075-1112

Rapp MS, Schaller P, Wolff M (2011) Aktienbasierte Langfristanreize im Rahmen der VorstandsverguetungEvidenz auf Basis Deutscher Prime Standard Unternehmen (Stock-Based Incentives in Executive Compensation Packages-Evidence from German Prime Standard Firms). Die Betriebswirtschaft 70(4):311-330

Rouen E (2020) Rethinking measurement of pay disparity and its relation to firm performance. Account Rev 95(1):343-378

Sanders WG (2001) Behavioral responses of CEOs to stock ownership and stock option pay. Acad Manag J 44(3):477-492

Shin JY, Kang SC, Hyun JH, Kim BJ (2015) Determinants and performance effects of executive pay multiples: evidence from Korea. ILR Review 68(1):53-78

Shue K, Townsend RR (2017) How do quasi-random option grants affect CEO risk-taking? J Financ 72(6):2551-2588

Sommer F, Lachmann M, Judith A (2013) Performanceabhängigkeit der Vorstandsvergütung in der Finanz-und Wirtschaftskrise-eine Analyse fixer und variabler Vergütungskomponenten unter Berücksichtigung von Corporate Governance-Mechanismen. ZfB Special 2:89-122

Sundaram R, Yermack D (2007) Pay me later: inside debt and its role in managerial compensation. J Financ 62(4):1551-1588

Tervio M (2008) The difference that CEOs make: an assignment model approach. Am Econ Rev 98(3):642-668

Wei C, Yermack D (2011) Investor reactions to CEOs' inside debt incentives. Rev Financ Stud 24(11):3813-3840

Wiseman RM, Gomez-Mejia LR (1998) A behavioral agency model of managerial risk taking. Acad Manag Rev 23(1):133-153

Xu J, Yang J (2016) Golden hellos: signing bonuses for new top executives. J Financ Econ 122(1):175-195

Publisher's Note Springer Nature remains neutral with regard to jurisdictional claims in published maps and institutional affiliations. 